Elsevier required licence: C2018. This manuscript version is made available under the CC-BY-NC-ND 4.0 license http://creativecommons.org/licenses/bync-nd/4.0/ 


\title{
Modeling the interrelationships among barriers to sustainable supply chain management in leather industry
}

\author{
Md. Abdul Moktadir \\ Institute of Leather Engineering and Technology, \\ University of Dhaka, \\ Dhaka-1209, Bangladesh. \\ Syed Mithun Ali \\ Department of Industrial and Production Engineering, \\ Bangladesh University of Engineering and Technology, \\ Dhaka-1000, Bangladesh.

\section{R. Rajesh} \\ Department of Management Studies (DoMS) \\ Indian Institute of Technology Madras \\ Chennai, India

\section{Sanjoy Kumar Paul*} \\ UTS Business School, University of Technology Sydney, Australia \\ *Corresponding author: sanjoy.paul@uts.edu.au (S. K. Paul)
}




\title{
Modeling the interrelationships among barriers to sustainable supply chain management in leather industry
}

\begin{abstract}
The leather industry of Bangladesh is facing considerable amounts of pressure to adopt sustainable supply chain management (SSCM). While there are some studies that have examined barriers to SSCM practices in developed and developing countries in various domains, these are not necessarily applicable to the Bangladeshi leather industry. To bridge this gap, it is crucial to identify most influential barriers to SSCM practices, particularly in the context of developing economies. Therefore, this study identifies such barriers and examines the causal relationships between them with an aim to facilitate the effective implementation of SSCM in the Bangladeshi leather processing industry. Thirty-five barriers to SSCM implementation were identified through a detailed literature review and a survey of leather processing industry experts. Among them, the most common 20 barriers were selected with the help of industry experts. Then, a blended, grey-based Decision Making Trial and Evaluation Laboratory (DEMATEL) approach was utilized to examine their interrelationships. The results demonstrate that nine barriers could be classified as "causal" and eleven as "influenced". 'Lack of awareness of local customers in green products' and 'lack of commitment from top management' took high priority in the causal group. 'Lack of reverse logistics practices' and 'Outdated machineries' were the most influenced barriers. This research uses a leather processing company as a case study for demonstrating the proposed model. The findings aim to support the leather processing industry in a structural way, so that industrial managers can identify the most influential barriers and work to eliminate them. This study may be useful to stakeholders to achieve sustainable development.
\end{abstract}

Keywords: Sustainable development; sustainable supply chain management; sustainable operations; leather industry; grey theory; DEMATEL.

\section{Introduction}

Environmental sustainability, green issues, and social sustainability have become increasingly popular among researchers and supply chain managers due to government regulations, customer expectations, and pressures imposed on buyers for green products. However, the rapid development of the leather industry in Bangladesh requires a concurrent increase in supply chain activities (Bai et al., 2017). An increase in such activities has implications for natural resource usage, waste generation, water pollution, emission of harmful gases and disruptions to the ecosystem (Luthra et al., 2011; Muduli et al., 2013; Rauer and Kaufmann, 2015). Meanwhile, sustainable supply chain management (SSCM) implementation can help to ensure long-term environmental, social and economic benefits for both leather companies and customers. In addition, SSCM practices can integrate environmental, social and supply chain management techniques with the goal of preventing or minimizing environmental 
degradation, improving social sustainability and enhancing economic sustainability (Diabat and Govindan, 2011).

However, the leather industry in Bangladesh is also facing tremendous global pressure to adopt SSCM practices in its traditional manufacturing systems. Although, in developed countries, there are currently competitive, regulatory and social pressures to adopt SSCM practices. Various organizations in developed countries have adopted diverse environmental management strategies, such as adopting cleaner technology (Grutter and Egler, 2004), achieving ISO 14001 certification (Junjie et al., 2007; Jabbour, 2015; Jabbour, 2010), implementing environmental management systems to minimize the adverse environmental effects of their supply chains and developing socially responsible supply chain management strategy (Nawrocka et al., 2009; Jabbour et al., 2012; Jabbour and Jabbour, 2016). Nowadays, developed countries are also used clean technologies to reduce waste for the protection of the environment (Pagell and Wu, 2009; Seuring and Müller, 2008; Walker and Jones, 2012; Zailani et al., 2012). So far, some authors tried to examine the barriers to green supply chain management (GSCM) and SSCM practices in the context of other country, particularly in other domain. Also, the lack of examining barriers to SSCM practices in the context of leather processing company has received lesser attention to researchers and practitioners. However, a few studies were conducted to examine the interactions of barriers to SSCM practices in the context of the developed and developing countries. Hence, this study adopts leather industry as example applications of barriers identification and finding interaction among identified barriers to SSCM implementation.

We select leather processing company supply chain for example applications due to multiple reasons. Firstly, the leather industry is responsible for polluting the environment and has a negative social impact. Secondly, the leather sector is the $2^{\text {nd }}$-highest ranked growth and investment potential in the export-earning segment due to the raw materials availability, cheaper labor cost, transportation facility etc. Thirdly, the leather industry in Bangladesh is facing tremendous global pressure to adopt SSCM practices in its traditional manufacturing systems. Fourthly, leather manufacturing companies are trying to implement sustainable supply chain management practices by incorporating environmental, social and economic issues. The above mentioned reason motivated us to evaluate the interactions of barriers to SSCM implementation in the context of the leather industry. Hereafter, this SSCM practices can help leather processing companies to integrate tipple bottom dimensions (e.g., environmental, economic, and social) to minimize or eliminate waste in all its forms, including harmful gas emissions, water pollution, soil pollution, and solid waste for environmental suitability; to enhance the economic performance including profit maximization, reputation building, gaining competitive advantages and to achieve the social responsibility.

\subsection{Motivation and Contribution}


Recent studies on sustainable and green supply chains have been conducted in developing countries in various domains. Govindan (2017) developed a conceptual framework for sustainable consumption and production practices in food supply chains. (Mangla et al., 2017) analyzed barriers to sustainable consumption and productions practices. Vanalle et al. (2017) investigated green pressures, practices, and performance within the Brazilian automotive supply chain. Kusi-Sarpong et al., (2016) developed a framework for green supply chain practices in the Ghanaian mining industry, while Sadaghiani et al. (2015) evaluated the external forces affecting supply chain sustainability in the oil and gas industry. Recent studies also show that in the next couple of decades, most Asian manufacturers will have to face several environmental and social issues (Mangla et al., 2017). To the best of our knowledge, the literature indicates that there has been no research that has analyzed and quantified the interaction of barriers to SSCM implementation in the context of leather industries.

In the Bangladeshi leather processing industry, traditional supply chain management practices need to be made more sustainable. In this regard, SSCM practices may help make traditional systems more sustainable by not only considering environmental issues, but also social and economic ones. Implementing SSCM practices in the context of the Bangladeshi leather industry will be challenging due to the numerous barriers that currently exist. In this sense, this research raises some questions:

a) What are the key barriers to the implementation of SSCM practices in leather processing companies' supply chains?

b) How can managers evaluate the cause and effect relationships between selected barriers?

The specific objectives of the present study are:

1. To identify the key barriers to the adoption of SSCM practices in the leather processing companies of Bangladesh.

2. To understand the cause and effect relationships between a selection of these barriers.

To fulfil these objectives, this paper adopts a two-phased methodology which includes 1) a literature review to identify major barriers and facilitate a deeper analysis of the leather processing industry, and 2) identification of common barriers and their relative impacts based on feedback from industry experts, using a grey-based Decision Making Trial and Evaluation Laboratory (DEMATEL) approach.

A "grey" number can be described as the number of uncertain data points which can generate a required outcome (Dong and Luo, 2006). The Decision Making Trial and Evaluation Laboratory (DEMATEL) approach can help to find structural relationships between barriers through analysis of related digraphs. DEMATEL can show the relationships between barriers; however, it is sensitive to data uncertainty. Combined grey-based DEMATEL can help to overcome such 
uncertainty. For this reason, we choose a grey-based DEMATEL approach for examining interrelationships between barriers so that industrial managers can clearly observe their causes and effects.

\subsection{SSCM and Decision-Making Methodology}

To deal with multi-criteria decision-making problems, it is necessary to utilize multi criteria decision analysis (MCDA) tools to analyze and rank the criteria. Several MCDA tools are available in the literature. The motive behind the use of grey-based DEMATEL tools is explained in the previous sub-section. Grey-DEMATEL has been applied in many fields, including the food packaging industry (Zhigang Wang et al., 2015), hospital services (Shieh et al., 2010), and the automotive spare parts industry (Wu and Tsai, 2011). The use of DEMATEL in various fields of SSCM is shown in Table 1.

\section{<Take in Table 1 about here>}

\subsection{Organization of the Paper}

The rest of the research paper is organized as follows: Section 2 presents the theoretical background of the study. The grey-DEMATEL methodology is discussed in Section 3. Section 4 describes a real-world application to Bangladeshi leather processing companies and models the barriers to their implementation of SSCM practices. Section 5 provides the results and a discussion of the present research. Theoretical and managerial implications are presented in Sections 6. Finally, conclusions, unique contribution and further research scope are provided in Section 7.

\section{Theoretical Background}

In this section, we discuss a detailed literature review on SSCM, sustainable supply chain management practices in the Bangladeshi leather industry, an overview of the leather industry in Bangladesh, and the proposed research methodology.

\subsection{Sustainable Supply Chain Management}

Sustainable supply chain management involves the management of environmental, economic and social impacts and encourages good manufacturing practices throughout the lifecycle of products (Mathivathanan et al., 2017). Sustainable supply chain management helps to link development and environmental issues, and to drive political and economic change locally, nationally, and globally (Mangla et al., 2017). It is applied to traditional supply chain management by considering environmental, economic, and social issues (Su et al., 2015).

Recently, SSCM practices have been of great concern around the world due to government regulations, customer expectations, and pressures imposed on buyers for green products (Marcon 
et al., 2017). Accordingly, SSCM, a cross-disciplinary field, has been growing in popularity both in industrial managers and researchers (Sarkis et al., 2011). Sustainable development is a pattern of resource use that aims to satisfy human needs while protecting natural resources. The literature on SSCM is still in the nascent stage. Carter and Rogers (2008) mentioned sustainability as a strategy for gaining long-term economic benefits via the key integration of environmental, social, and economic factors. Many researchers have indicated SSCM can be an integrated approach for minimizing ecological degradation (Esfahbodi et al., 2016a; Harms, 2011). Sustainability has become a popular global concern and hence, motivated industrial organizations are modifying their supply chain activities and considering the environmental, social, and economic impacts of their supply chains (Carter and Easton, 2011; Carter and Rogers, 2008). Sustainability is taken into consideration because of legislation, public awareness, and competitive opportunity. From this point of view, SSCM is an activity that helps to modify traditional supply chains. This modification is part of the sustainable development of an organization. A truly sustainable organization can simultaneously achieve social, environmental and economic benefits.

A wide variety of issues, like supply chain risk mitigation and sustainability, are incorporated in SSCM. Along with this, the SSCM approach includes product safety and performance, protection of the environment, and ensuring good governance. Targets of SSCM include reducing operational energy consumption, increasing renewable energy use, reducing water consumption, reducing hazardous waste generation, and reducing environmental impacts from manufacturing etc. (Jayant and Azhar, 2014; Rauer and Kaufmann, 2015; Walker et al., 2008). During recent times, micro-economic applications have been investigated in the fields of engineering, operations, and supply chains (Sarkis, 2012). In most cases, sustainability was described as ecological sustainability, with little recognition of its social and economic aspects (Jabbour et al., 2013b; Jabbour et al., 2015). Recent studies on SSCM management practices show how the pressures from government, stakeholders and customers aid in effectively adopting sustainability into existing supply chain networks (Bouzon et al., 2016a; Egilmez et al., 2014). Given their adverse effects on the environment, top priority should be given to the implementation and maintenance of sustainable supply chains. This can ensure a developed infrastructure for future generations in developing countries. A summary of the existing literature on SSCM and green practices is shown in Table 2.

\section{<Take in Table 2 about here>}

\subsection{Sustainable Supply Chain Management Practices in the Bangladeshi Leather Industry}

Bangladesh is a developing country with a history of pursuing economic growth without considering the environment. Rapid economic development and overpopulation have destroyed many of the country's natural resources through pollution of the water, air, and soil, etc. (Hoque and Clarke, 2013). The sustainability of supply chains has yet to become a matter of consideration due to a lack of legislation. Hence, it is important to develop a sustainable 
manufacturing framework in such a way that environmental depletion can be minimized (Diabat and Govindan, 2011). Eco-friendly and clean technologies have played important roles in the sustainable development of the leather sector in Bangladesh. Hence, the implementation of SSCM practices will become one of the dominating factors in the survival of the leather industry in the near future. Also, scientific research and knowledge will definitely help the leather industry to adopt the SSCM operational procedures, and to motivate government to implement SSCM legislation. Operational implementation of SSCM in industry should be a part of compliance maintenance, as per the International Standard Organization (ISO). Most of the research conducted up to now has been focusing on developed countries (Zaabi et al., 2013) Therefore, this research helps to develop a sustainable supply chain framework by identifying and analyzing the various barriers to SSCM in the leather processing industry of Bangladesh. This may help new companies to set up sustainable supply chains, and help existing companies to make their supply chains more sustainable.

\subsection{A Brief Overview of the Bangladeshi Leather Industry}

The government of Bangladesh has indicated that the leather industry has the $2^{\text {nd }}$-highest ranked growth and investment potential in the export-earning segment. Due to its high availability of raw materials, finished leather and less manufacturing cost, the leather sector has already been pronounced a potential sector of the country. Currently, Bangladesh delivers quality bovine, ovine and caprine leather (wild ox, bovine, sheep and goat) to local and global markets that demand quality skins (Paul et al., 2013).

Apart from the export of quality leather, Bangladesh also exports a huge amount of leather goods like ladies handbags, backpacks, wallets, belts, travel bags, and leather footwear to developed countries like China, France, Italy, Germany, USA, UK, Japan, Spain, and the UAE (Technical Report, 2013). The entire leather sector of Bangladesh meets only 0.5\% of the world's leather demand, which worth is USD 75 billion (Paul et al., 2013).

Approximately 187 tanneries are located in the Hazaribagh area of Dhaka, which produce 180 million square feet of hides and skins per year. The supply-cycle of raw skins and hides is $40-45 \%$ of the annual supply available during the festival of Eid-ul-Azha, which is the major source of producing quality leather. However, only about 40 tanneries are utilizing a major portion of their installed capacity, indicating that "sickness" exists in the sub-sector. This leather sector has a long-established tanning industry which produces around $1.13 \%$ of the world's leather from a local supply of raw hides and skins. Most of the tanneries in Bangladesh do not have proper effluent treatment plants and thus generate $20,000 \mathrm{~m}^{3}$ of tannery effluent and 232 tons of solid waste per day. This effluent and solid waste is a critical issue for sustainable manufacturing practices in the leather industry. To minimize this waste, specific cleaner technologies must be adopted as part of SSCM practices in Bangladesh's leather industry (Technical Report, 2013). 
A newly established "leather zone" is expected to bring substantial changes to the leather industry by introducing centre effluent treatment plant (CETP) which will help to reduce water and soil pollutions. Also this will help to implement sustainable manufacturing system. Overall this will help to increase the image in global market. Therefore, this sustainable manufacturing practices and cleaner production will be a key issue for the development of the nation. In this regard, the leather sector of Bangladesh requires sustainable manufacturing practices to achieve international standards in technical, environmental, safety, and commercial aspects, and to attain competitiveness in the world market. An export earnings summary of Bangladeshi leather and leather products is shown in Table 3.

\section{$<$ Take in Table 3 about here $>$}

\subsection{Research Methodology}

To apply the research framework to a real-life problem, we need to finalize the most common barriers to the implementation of SSCM. Based on our literature survey of implementation barriers to SSCM, a deep analysis of the leather processing industry, and discussions with a team of four experts from the case company, 35 barriers was identified. From these 35 barriers, 20 were selected for analysis, and their interactions were evaluated via the grey-based DEMATEL approach. The proposed research framework is shown in Fig. 1.

\section{<Take in Fig. 1 about here>}

\section{Solution Methodology}

Grey theory, from grey sets, was first initiated by Deng (1989). Grey systems methodology can manage many of the uncertainties which arise from human decisions (Dong and Luo, 2006; Fu et al., 2001). Most importantly, grey theory can be combined with any decision-making methods to improve the quality of judgments (Asad et al., 2016; Li et al., 2007; Liu et al., 2011). The modified CFCS (converting fuzzy values into crisp scores) method helps to amend grey numbers into crisp numbers by a three-step procedure (Fu et al., 2012). One of the main advantages of a grey system is that it can give acceptable outcomes using small amounts of data. Therefore, grey theory was used to solve various uncertainty problems with discrete data.

The decision-making trial and evaluation laboratory (DEMATEL) method is best suited for analyzing complex causal relationships among various factors (Hsu et al., 2013; Wang et al., 2012). DEMATEL is a structural modeling approach which can represent the interdependence of various factors and their cause-effect relationships in the form of a digraph (Su et al., 2015). In the DEMATEL method, all the factors (which, in this study, are barriers to SSCM) are divided into cause and effect groups to help identify their causal relationships. The procedure for greyDEMATEL methodology is described as follows:

Step 1: Obtain the initial relation matrices 
Let the number of identified common barriers to SSCM practices be $n$, and the respondents chosen be $l$. Each respondent $(k)$ is given the task of evaluating the direct influence of barrier $i$ over barrier $j$ on an integer scale ranging from [0, 0.1], [0.1, 0.3], [0.2, 0.5], [0.4, 0.7], [0.6, 0.9], $[0.9,1]$, indicating no influence, very low influence, low influence, medium influence, high influence and very high influence among the $n$ barriers. Thus, set up $l$ initial comparison relation matrices based on the ratings obtained from the respondents.

Step 2: Formulate the grey relation matrices

Upper and lower values of the grey scales need to be identified from the integer rating scale (JuLong, 1982; Julong, 1989), i.e.,

$$
\otimes y_{i j}{ }^{k}=\left(\otimes y_{i j}{ }^{k}, \bar{\otimes} y_{i j}{ }^{k}\right) \text {. }
$$

Where, $1 \leq k \leq l ; 1 \leq i \leq n ; 1 \leq j \leq n$.

The initial relation matrices are converted into grey relation matrices based on the obtained grey values, i.e.,

$\left[\otimes y_{i j}^{1}\right],\left[\otimes y_{i j}^{2}\right],\left[\otimes y_{i j}^{3}\right], \ldots \ldots . .,\left[\otimes y_{i j}^{l}\right]$.

Step 3: Calculate the average grey relation matrix

The average grey relation matrix $\left[\otimes \tilde{y}_{\mathbf{i j}}\right]$ is computed (Kose et al., 2013; Lin et al., 2004) from $l$ grey relation matrices, $\left[\otimes y_{i j}{ }^{k}\right] ; k=1-l$ as,

$$
\bar{y}_{i j}=\left(\frac{\sum_{k} \otimes y_{i j}{ }^{k}}{l}, \frac{\sum_{k} \bar{\otimes} y_{i j}{ }^{k}}{l}\right) .
$$

Step 4: Calculate the crisp relation matrix from the average grey relation matrix

The grey values are modified into crisp values by the modified CFCS method (Arikan et al., 2013; Dou et al., 2014) following a three-step procedure described as follows:

(i) Normalization of the grey value

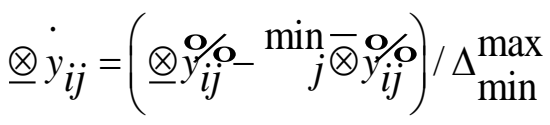

Where $\otimes y_{i j}$ indicates the normalized lower limit value of the grey number $\otimes \mathscr{y}_{i j}$. 


$$
\bar{\otimes} \dot{y}_{i j}=\left(\bar{\otimes} y_{i j}{ }_{-} \min _{j} \bar{\otimes} y_{i j}{ }^{\circ}\right) / \Delta_{\min }^{\max }
$$

Where $\bar{\otimes} \dot{y}_{i j}$ indicates the normalized upper limit value of the grey number $\otimes \bar{y}_{i j}$

$$
\Delta_{\min }^{\max }={ }_{j}^{\max } \bar{\otimes} y_{i j}-{ }_{j}^{\min } \otimes y_{i j}
$$

(ii) Calculating total normalized crisp value

$$
Z_{i j}=\left(\frac{\left(\underline{\otimes} \dot{y}_{i j}\left(1-\underline{\otimes} \dot{y}_{i j}\right)\right)+\left(\bar{\otimes} \dot{y}_{i j} \times \bar{\otimes} \dot{y}_{i j}\right)}{\left(1-\underline{\otimes} \dot{y}_{i j}+\bar{\otimes} \dot{y}_{i j}\right)}\right) .
$$

(iii) Computing the final crisp values

$$
Z^{*}=\left(\min _{j} \otimes y_{i j}{ }^{+}\left(Z_{i j} \times \Delta_{\min }^{\max }\right)\right),
$$

And $Z=\left[Z_{i j}^{*}\right]$

Step 5: Calculate the normalized direct crisp relation matrix

In this step, the normalized direct crisp relation matrix $(P)$ is obtained by computing $Q$ and multiplying $Q$ with the average relation matrix $Z$. That is,

$$
Q=\frac{1}{\max _{1 \leq i \leq n} \sum_{j=1}^{n} Z_{i j}^{*}},
$$

And, $\mathrm{P}=\mathrm{Z} \times \mathrm{Q}$

Each element in matrix $P$ falls between zero and one.

Step 6: Compute the total relation matrix

In this step, the total relation matrix $(T)$ is calculated by the following equation,

$$
T=P \times(I-P)^{-1}
$$

Where $I$ is the identity matrix.

Step 7: Obtain the cause and effect parameters by summing rows and columns Assume $t_{i j}$ denotes the elements in the total relation matrix, $T$. Let $r$ and $c$ be defined as $n \times 1$ and $l \times n$ vectors representing the sum of row elements and sum of column elements for the total relation matrix $T$, respectively. If $r_{i}$ represents the sum of the $i^{\text {th }}$ row elements in matrix 
$T$, then $r_{i}$ summarizes both the direct and indirect effects of barrier $I$ towards the other barriers. If $c_{j}$ represents the sum of the $j^{\text {th }}$ column elements in matrix $T$, then $c_{j}$ summarizes both the direct and indirect effects received by barrier $j$ from other barriers, i.e.,

$$
\begin{aligned}
& r_{i}=\sum_{j=1}^{n} t_{i j} \forall i \\
& c_{j}=\sum_{i=1}^{n} t_{i j} \forall j
\end{aligned}
$$

When $j=i$, the sum $\left(r_{i}+c_{j}\right)$ indicates the total effects given and received by barrier $i$; i.e.,

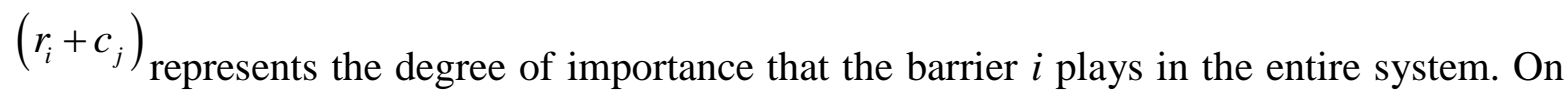
the other hand, $\left(r_{i}-c_{j}\right)$ outlines the net effect that the barrier $i$ contributes to the entire system. If $\left(r_{i}-c_{j}\right)$ is positive, barrier $i$ is the net cause. Barrier $i$ indicates the net effect if $\left(r_{i}-c_{j}\right)$ comes out to be negative value.

Step 8: Compute the threshold value from the total relation matrix and plot the digraphs for the total relation matrix, $T$, providing information on how one barrier affects another barrier. A threshold value needs to be calculated to avoid any complexity in plotting the digraph. It is assumed that values greater than the threshold have higher influence during the adoption of SSCM practices. Threshold values are usually computed as the sum of the mean values and the standard deviation of the elements in the total relation matrix $T$. In the digraph, the causal relations are plotted from the dataset of $\left(\left(r_{i}+c_{j}\right),\left(r_{i}-c_{j}\right)\right) \forall i=j$.

\section{Application of the proposed framework}

The proposed research framework was applied to a leather processing company from Hazaribagh, Dhaka, which we shall call "XYZ". This company was selected as a representative case for the implementation of SSCM practices. XYZ is a global export-oriented leather processing company which began manufacturing in 1977. It exports crust and finished leather to developed countries like Japan, Korea, Italy, and China. It also supplies finished leather for a footwear company of their own brand codename, referred to here as "ABC footwear". In fiscal year 2015-2016, this leather processing company earned USD 35 million. Due to its remarkable contribution to economic development, it is important to consider SSCM practices in their production. To improve sustainability in their supply chain management practices is a recent concern and has emerged as the subject of our research. 
Recently, XYZ became interested in implementing SSCM practices to sustain their business in the global market. Therefore, they have strived to identify the barriers to the adoption of SSCM in their supply chains, and the interactions between those barriers. This research helps to achieve this goal.

\subsection{Data Collection}

In the process of data collection, a team of four experts from XYZ was formed. The required data were collected from industry professionals. Data collection was performed in two phases, as outlined below:

Phase 1: Finalizing the most common barriers to implementing SSCM practices

At first, we identified 35 barriers to SSCM practices through a literature survey, and deeper survey on leather processing companies. These barriers may be applicable to specific industry categories and specific countries. To identify the most relevant barriers in the social, economic, and technological context of the Bangladeshi leather industry, experts were asked to add or delete barriers to SSCM practices from the listed 35 barriers. The four experts comprised a supply chain executive, production manager, logistics executive, and leather technologist from the XYZ company. They had sufficient knowledge of supply chain management, operations, risk management and logistics, and each had over 15 years' professional experience. We collect responses from the experts by providing questionnaires and then we arranged several discussion sessions to consolidate the information. Subsequently, 20 barriers from four major groups were identified. We then used input from the experts to evaluate comparisons of the identified barriers for the purpose of developing a grey-DEMATEL model.

Phase 2: Evaluation of the comparison of identified barriers to SSCM practices

We communicated the objectives and methodology of our research to the expert panel and asked them to fill a pair-wise comparison matrix, which was necessary for developing the greyDEMATEL model.

The barriers to adopting SSCM practices that were considered in this study, and related literature, is summarized in Table 4. A summary of codes used to identify the most common barriers is provided in Table 5.

\section{$<$ Take in Table 4 about here $>$}

\section{<Take in Table 5 about here>}

The application of the proposed framework to the case of leather processing company $\mathrm{XYZ}$ is explained as follows:

\section{Step 1:}


Experts helped to evaluate the direct influence of one barrier to the other barriers on linguisticbased grey scales, as discussed in Section 3. Four initial $20 \times 20$ comparison matrices were formulated based on the integer grey scale ratings.

\section{Step 2:}

In this step, four initial grey relationship matrices were formulated $\left(\left[\otimes y_{i j}{ }^{1}\right],\left[\otimes y_{i j}{ }^{2}\right],\left[\otimes y_{i j}{ }^{3}\right],\left[\otimes y_{i j}{ }^{4}\right]\right)$ based on the influence ratings obtained from the four supply chain experts using Equation (1). The obtained matrix for Expert 1 (supply chain executive) is shown in Table A1 in Annexure 1. The matrices for Expert 2 (production manager), Expert 3 (logistics executive) and Expert 4 (leather technologist) were constructed similarly.

\section{Step 3:}

In order to achieve homogeneity of judgment, in this step, equal weightings were assigned to all experts and we computed the average grey relation matrix $\left(\left[\otimes y_{i j} /{ }^{\dagger}\right)\right.$ using Equation (2). This average grey relation matrix is shown in Table 6.

\section{$<$ Take in Table 6 about here>}

\section{Step 4:}

In this step, using a three-step procedure involving the modified CFCS method, the crisp relation matrix $Z$ was formulated from the average grey relation matrix. The crisp relation matrix was computed using Equations (3), (4), (5), (6), (7) and (8), and is shown in Table A2 in Annexure 1.

\section{Step 5:}

The normalized direct crisp relation matrix $P$ was constructed from the crisp relation matrix by normalization using Equations (9) and (10), and is shown in Table A3 of Annexure 1.

\section{Step 6:}

The total relation matrix $T$ was constructed using Equation (11), and is shown in Table 7.

\section{$<$ Take in Table 7 about here>}

\section{Step 7:}

Let $r$ and $c$ be defined as $20 \times 1$ and $1 \times 20$ vectors denoting the sum of the row values and the sum of the column values for the total relation matrix $T$, respectively. Using Equations (12) and (13), $r_{i}$ and $c_{j}$ values are computed. The cause and effect parameters $\left(r_{i}+c_{j}\right)$ and $\left(r_{i}-c_{j}\right)$ were constructed from the total relation matrix $(T)$ for values $i=j$, and are shown in Table 8 .

<Take in Table 8 about here> 


\section{Step 8:}

The cause and effect digraph was developed using the total relation matrix. A threshold value $(\theta=0.178)$ was calculated by adding the standard deviation $(\sigma)$ to the mean $(\mu)$ of the elements in the total relation matrix $T$, to filter out comparably negligible cause-effect among different barriers. Figure 2 presents the resulting digraph showing the cause-effect relationships among the common barriers, plotted from the data set of $\left(\left(r_{i}+c_{j}\right),\left(r_{i}-c_{j}\right)\right) \forall i=j$. The arrow represents the direction from cause barriers to effect barriers. Two-way significant relationships between barriers are presented as dotted lines, whereas one-way relationships are indicated using solid lines (Fig. 2).

\section{$<$ Take in Fig. 2 about here>}

\section{Results and Discussion}

Cause-effect relations among major barriers to SSCM for the study supply chain were plotted and are summarized in Table 9. As stated earlier, a grey-based DEMATEL approach was applied to analyze the most influential barriers to the adoption of SSCM practices. A threshold value $(\theta)$ of 0.178 was considered in this research to reduce the complexity of the digraph and to eliminate some of the minor barrier effects. Threshold values were computed from the total relation matrix, $T$. The barriers were ranked in terms of importance, based on $\left(r_{i}+c_{j}\right) \forall i=j$ values as follows; KS1 $>\mathrm{KS} 2>\mathrm{S} 1>\mathrm{F} 1>\mathrm{S} 2>\mathrm{T} 3>\mathrm{KS} 4>\mathrm{E} 4>\mathrm{T} 4>\mathrm{E} 1>\mathrm{F} 2>\mathrm{T} 1>\mathrm{E} 3>\mathrm{E} 2$ $>\mathrm{T} 2>\mathrm{F} 3>\mathrm{S} 3>\mathrm{KS} 3>\mathrm{F} 4>\mathrm{S} 4$.

\subsection{Cause Group}

The causal barriers were ranked based on $\left(r_{i}-c_{j}\right) \forall i=j$ values as follows: $\mathrm{E} 4>\mathrm{KS} 2>\mathrm{F} 1$ $>\mathrm{E} 1>\mathrm{S} 1>\mathrm{S} 2>\mathrm{KS} 4>\mathrm{KS} 1>\mathrm{T} 3$ (Fig. 2). In this causal group, Lack of awareness of green products in local customers (E4) and Lack of commitment from top management (KS2) seemed to be the crucial driving barriers. These can generate effects in many of the other barriers. We discussed the results with the industry experts and they accepted that these barriers were major ones. Lack of awareness in local customers (E4) is one category of environmental issues which can obstruct green supply chain implementation. When customers lack awareness of the environmental impacts of products, top management will be less interested in implementing SSCM.

Lack of commitment from top management (KS2) was among the major causal barriers to SSCM implementation. In Bangladesh, top management is not interested in implementing SSCM because of insufficient funds. Such implementation requires large investment. Hence, this barrier emerges as a big issue during SSCM implementation. Integrating SSCM practices into the total supply chain system needs large investments to modify existing systems and, hence, top 
management do not want to implement SSCM in their companies, especially in leather processing industry.

The third most importance causal barriers to SSCM implementation is the cost of sustainability and economic conditions (F1). Therefore, a combination of the cost of sustainable practices and the poor economic conditions existing in Bangladesh hinders the implementation of SSCM in traditional supply chain systems.

Lack of eco-literacy amongst supply chain partners (E1) was identified as the fourth causal barrier to SSCM. In Bangladesh, many supply chain partners are not conscious of the ecological implications of products, which hinder the implementation of SSCM. The other causal barrier is lack of support and guidelines from regulatory authorities (S1). This is one of the barriers that has the most influence on other barriers to SSCM implementation in the leather processing industry. In Bangladesh, the regulatory authorities do not actively support SSCM practices and have no regulations to encourage their implementation in the manufacturing industry. This barrier a major obstacle. It is necessary to eradicate this barrier to reduce its influence over the other barriers to SSCM implementation.

Absence of society pressure (S2) is found as another important causal barrier to the implementation of SSCM practices. Bangladesh is an overpopulated country. Most of the people are not aware of green practices, sustainability, and environmental issues. This, in turn, badly affects the manufacturing industry. There is a great opportunity to remove other barriers by increasing society's general awareness about the environmental impacts of the products they consume.

Lack of training and education about sustainability (KS4) is one of the knowledge and support-related causal barriers. Introducing training and education may help in adopting SSCM practices in the leather processing industry because the employers and owners of leather companies do not have sufficient knowledge of sustainability issues. By introducing proper training, the problem can be rectified to a certain extent.

Information gap (KS1) was the eighth-most important causal barrier. An overall lack of information on sustainability, green supply chains, reverse logistics, social sustainability, and economic sustainability is one of the major barriers to adopting SSCM practices. Overcoming this barrier can help to implement SSCM practices in leather processing industry.

The last but not least was the lack of cleaner technology (T3). The lack of clean technologies in the leather processing industry is largely responsible for its environmental impacts. Especially because waste water is often discharged directly into rivers, thereby polluting the air, soil, and water. Chemicals used in tannery operations produce solid waste which can directly pollute water and soil. Introducing cleaner technology can help to modify the current situation and ultimately improve SSCM practices. 


\subsection{Effect Group}

The "effect" group can be sorted on the basis of $\left(r_{i}-c_{j}\right) \forall i=j$. As shown in Fig. 2, the rank order of effect barriers was $\mathrm{T} 2>\mathrm{S} 3>\mathrm{S} 4>\mathrm{F} 4>\mathrm{E} 2>\mathrm{F} 3>\mathrm{KS} 3>\mathrm{F} 2>\mathrm{T} 1>\mathrm{T} 4>\mathrm{E} 3$. These eleven barriers are directly influenced by the nine causal barriers to SSCM practices in the leather processing industry. Resistance to change and adopting innovation (T2) was near to the causal group and hence, was less influenced by causal barriers. Other effect barriers were: lack of demand and pressure for lower prices (S3), less business-friendly policies (S4), green power shortage (F4), lack of environmental requirements (E2), lack of funds for sustainable supply chain practices (F3), limited access to market information (KS3), capacity constraints (F2), lack of technical expertise (T1), outdated machinery (T4), and lack of reverse logistics practices (E3). All of these barriers are easily influenced by the causal barriers. During establishment of SSCM practices, it is necessary to identify the cause and effect barriers so that action can be taken against them. This research can help managers to identify these cause-effect relationships and gain practical insights to introducing SSCM practices in the leather processing industry.

\subsection{Correlations between the barriers}

According to $\left(r_{i}+c_{j}\right) \forall i=j$, the barriers can be ranked as follows $\mathrm{KS} 1>\mathrm{KS} 2>\mathrm{S} 1>\mathrm{F} 1>$ $\mathrm{S} 2>\mathrm{T} 3>\mathrm{KS} 4>\mathrm{E} 4>\mathrm{T} 4>\mathrm{E} 1>\mathrm{F} 2>\mathrm{T} 1>\mathrm{E} 3>\mathrm{E} 2>\mathrm{T} 2>\mathrm{F} 3>\mathrm{S} 3>\mathrm{KS} 3>\mathrm{F} 4>\mathrm{S} 4$. Information gap (KS1) seemed to have the highest correlation with other barriers. This is because information about SSCM can obstruct to adopt SSCM practices in existing supply chains and for new entrepreneurs. In Bangladesh, the major obstacle is information gap. Insufficient knowledge about SSCM is a major barrier to SSCM implementation. In every branch of the supply chain network of the Bangladeshi leather industry, people are unaware of green products, reverse logistics, social issues, environmental requirements, and sustainability. The ultimate result is pollution of the water, soil, and air, etc. Bangladesh needs to create various SSCM training and educational facilities that ensure that manufacturers and customers are conscious of products' environmental impacts.

In this study, it was perceived that each barrier is directly influenced other barriers. In Fig. 3, the barriers located above the $x$-axis have most influence over the network and are indicated as causal group barriers. The other barriers, which are located under this line, are indicated as effect barriers. The barriers in Fig. 3 can be divided into four regions for accurate analysis of their influences. In Fig. 3, Zone 1 represents the barriers with the least influence on other barriers, and their potential importance is low. Resistance to change and adopting innovation (T2), lack demand and pressure for lower prices (S3), less business-friendly policies (S4), green power shortages (F4), lack of environmental requirements (E2), lack of funds for sustainable supply chain practices (F3), limited access to market information (KS3), lack of technical expertise 
(T1), and lack of reverse logistics practices (E3) are the barriers in this zone. Zone 2 also represents the causal relationships among the different barriers which have a low influence on SSCM implementation. In this research, there is no barrier in Zone 2.

Zone 3 represents the barriers which have the highest significance. These barriers are located in the causal group and should be considered for SSCM implementation. These barriers can help managers to undertake proactive and reactive steps to adopt SSCM practices in their supply chain networks. Included in Zone 3 are the barriers of Lack of awareness of local customers in green products (E4), lack of commitment from top management (KS2), cost of sustainability and economic conditions (F1), lack of eco-literacy amongst supply chain partners (E1), lack of support and guidelines from regulatory authorities (S1), absence of societal pressure (S2), lack of training and education on sustainability (KS4), information gaps (KS1), and lack of cleaner technology (T3). Zone 4 indicates the barriers which have high significance but are in the effect group. In this zone, capacity constraints (F2) and outdated machinery (T4) seem to be the high significant barriers which have high influence during SSCM practices by other causal barriers. Ranking of the importance of barriers, for both the cause and effect groups, is shown in Table 9.

<Take in Fig. 3 about here>

$<$ Take in Table 9 about here $>$

\subsection{Comparison with existing literature}

The results reveal that 'Lack of awareness of local customers in green product (E4)' found as topped causal barriers to SSCM implementation in the context of leather industry. Contrary to our findings, Zaabi et al., (2013) studied on barrier to assess the interaction among barriers to implementing SSCM in the context of India, however, their evaluation process does not consider this barrier. A study by Bouzon et al., (2016) showed that the barrier 'lack of customer awareness' received the least priority in the global rank in the context of Brazil for reverse logistics implementation. Our finding also aligns with the present macro perspective challenges of the business organizations in the context of the globe. As for example, Esfahbodi et al., (2016) affirmed that increasing pressure from consumers may force manufacturing industry to adopt SSCM practices in emerging economies. Chen et al., (2006) and Raut et al., (2017) reported that costumers' environmental awareness may act as a crucial driving force for the manufacturing companies to implement the SSCM practices. Govindan et al., (2014) showed that lack of customer awareness for greening the supply chain is the crucial barrier for Indian manufacturing industries. A recent study by Moktadir et al., (2018) argued that customer awareness towards sustainable manufacturing practices and a circular economy may help leather processing companies modify the liner economy to circular economy. Andiç et al., (2012) affirmed that environmental conscious consumers able to force the manufacturing company though the choice of green products. The above mentioned literature confirmed that lack of customer awareness 
may act as crucial causal driving barriers which can drive the effect group barriers simultaneously during implementing SSCM in the leather industry of Bangladesh.

Next the 'Lack of commitment from top management (KS2)' barrier received the second most priority in the causal group. Contrary to our findings, several authors claimed that this barrier may not act as causal barrier rather than influenced barrier (Zaabi et al., 2013; Govindan et al., 2014). Zaabi et al., (2013) showed that the lack of top management commitment has received less driving power but has received high dependency which indicated that lack of commitment from top management may not able to drive the company to adopt SSCM practices for the Indian manufacturing companies. Govindan et al., (2014) also claimed that top management involvement may not act as crucial barriers in the context of Indian manufacturing industry. Bouzon et al., (2016) evaluated the barriers to reverse logistics implementation; however they did not take this barrier for the final evaluation process for the Brazilian manufacturing companies. Raut et al., (2017) investigated critical success factor of SSCM practices in the context of oil and gas industry. They also ignored the contribution of top management for SSCM implementation in the context of India whereas our findings cofirm that top management commitment may drive the leather industry towards sustainable manufacturing practices. Mittal et al., (2013) conducted a study on drivers and barriers to green manufacturing in the context of India and Germany and they reported that the barrier 'lack of commitment from top management' received the least priority also for both countries. Our finding also supported some previous findings. As for example, Luthra et al., (2017) evaluated the driver sustainable to production and consumption implementation in the context of Indian and suggested that the support from management can help manufacturing industry continuously to improve the sustainable manufacturing practices, Gandhi et al., (2015) confirmed that lack of top management commitment may act as causal barriers because of top management commitment may act as decision power for the successful implementation of green practices, Moktadir et al., (2018) also suggested that for sustainable manufacturing practices, top management may drive the total implementation process, Ali et al., (2017) argued that lack of top management commitment may hinder the revere logistics practices for greening the supply chain in the domain of computer supply chain for Bangladesh.

Cost of sustainability \& economic condition (F1) got the third position in the causal group. In this case, our finding matched with present macro perspective challenges of the business organizations in the context of the globe. As for example, Nordin et al., (2014) demonstrated that for the implementation of sustainable manufacturing practices in Malaysian manufacturing firms needs huge cost as this require conversion of conventional manufacturing system. Research from Shrivastava, (1995) claimed that implementation of SSCM practices is unprofitable and it requires more investment. Therefore, similar to Giunipero et al., (2012), our finding indicated that cost of sustainability and economic condition may act as one of the stronger barriers in the context of leather processing companies. Min and Galle, (2001) showed that green purchasing for GSCM implementation requires huge investment. Zaabi et al., (2013) demonstrated that cost 
of sustainability \& economic condition is a crucial causal barrier for Indian manufacturing industries for SSCM implementation. Bhanot et al., (2015) reported that cost of sustainability is one of the main barriers for sustainable manufacturing practices. Some authors (Green et al., 2013; Liu et al., 2012) pointed out that SSCM practices may potentially help organizations to achieve better economic performance in the global business networks. The above findings ensure that the cost of sustainability and economic condition is aligned with our findings and the present macroeconomics challenges for SSCM implementation.

Lack of eco-literacy amongst supply chain partner (E1), identified as a fourth ranked causal barrier that may act as significant causal barrier for the SSCM implementation. Eco-literacy amongst supply chain partner can act as a crucial driving barrier for SSCM implementation. Vachon, (2007) argued that literate supplier can influence the organizations to adopt SSCM practices as SSCM practices can help to reduce negative environmental, economic and social effect. Literate supplier can force the companies to strictly follow the environmental rules and regulations as agreed by (Mathiyazhagan et al., 2013; Govindan et al., 2014a; Vachon, 2007; Zhu and Sarkis, 2006). Moktadir et al., (2018) suggested that supplier can impose pressure over companies or organizations to implement the SSCM practices to comply the environmetal and social sustanability of the leather manufactuirng. Although several researchers avoid this barrier to assess the impact of barriers for SSCM implementations as for example Walker et al., (2008) explored barriers to implement green supply chain management initiatives in the perspective of private and public sectors but unfortunately they did not mention the contribution of supplies for GSCM initiative. Similarly Zaabi et al., (2013) avoided this barriers to find the interactions of barriers in the context of India. Finally, it is evident from the litearture search that lack of ecoliteracy amongest supply chain partner can drive the other influenced barriers for SSCM practices in the context of Bangladesh.

Our findings indicates that Lack of support and guideline from regulatory authority (S1) can influence other effect group barriers significantly as this barrier has received fifth position in the priority ranking. In Bangladesh, the regulatory authorities do not actively support SSCM practices for the leather industry. However, the support and guideline from regulatory authority is mandatory for SSCM implementations. Many previous researches on green supply chain, reverse logistics, green purchasing, sustainable supply chain implementations indicated that support and regulations from regulatory authority can act as key driving fuel for sustainable development of a country (Govindan et al., 2014b; Walker et al., 2008; González-Torre et al., 2010; Prakash and Barua, 2015). Zhu et al., (2007) believed that guideline from regulatory authority may be able to force the manufacturing companies to implement green practices. Lin, (2011) evaluated the green supply chain management performances and he suggested that regulations may able to drive the total implementation system greatly. Contrary to our findings, Zaabi et al., (2013) mentioned that appropriate regulations may not act as causal barriers for SSCM implementations rather than can act as an effect group barrier for Indian manufacturing industry. 
Pressure from nongovernment organizations (NGO) and environmental interest community can motivate industrial managers and decision makers to undertake SSCM practices in order to increase their global reputations, to minimize social and environmental impact and to improve the supply chain efficiency (Lin, 2011; Vafadarnikjoo, 2014a, 2014b). Similar to Henriques and Sadorsky, (1996), our findings suggested that society pressure may influence the other barriers greatly to improve the sustainability of the supply chains. Our finding also matched some previous research on green supply chain implementation literature as for example Muduli et al., (2013) investigated the barriers to green supply chain management in Indian mining industries and they mentioned that lack of pressure from society may act as crucial barrier. Moktadir et al., (2018) reported that society pressure can help to improve the sustainable manufacturing practices in the context of leather industry. Hence, absence of society pressure (S2) has received the sixth position in the causal group barrier due to leather industry faces lack of pressure from society as well as from NGO. The improvement of this barrier may influence the other effect group barriers. Therefore, improvement of this barrier can drive the leather companies towards sustainable development. Our findings also contradicted previous some studies as for example Xia et al., (2015) investigated the internal barriers for automotive parts remanufacturers in the context of China and they did not blame that society pressure can influence the automotive industry for remanufacturing practices, Zaabi et al., (2013) tried to find the interactions among SSCM implementing barriers and they also avoided the effect of society pressure for SSCM implementation process in the context of India.

In this study, Lack of training and education about sustainability (KS4) has received the seventh position in causal group. Contrary to our research findings, Nordin et al., (2014) reported that training and education about sustainability may not act as barriers to sustainable manufacturing practices for Malaysian manufacturing firms. Tay et al., (2015) conducted a review on drivers and barriers towards SSCM practices and they did not consider training and education about sustainability as a barrier for SSCM implementation. Lieder and Rashid, (2016) demonstrated that social awareness is crucial for a successful transition from a linear economy to a circular economy. Bhanot et al., (2015) and Teixeira et al., (2016) pointed out that training and education about suitability may act as enabler for sustainable manufacturing practices. Several researchers (Ametepey et al., 2015; Bhanot et al., 2017, 2015; Diabat et al., 2014) mentioned that training and education has a lack influence on SSCM practices. Our findings also matched some studies on various domain as for example (Raut et al., 2017) investigated the critical success factors of SSCM practices and they mentioned that training may act as causal factor and it can facilitate the implementation process, Moktadir et al., (2018) investigated the drivers to sustainable manufacturing practices and a circular economy in the context of leather industry and claimed that training and education has a great influence on sustainable manufacturing practices, Zaabi et al., (2013) believed that training and education about sustainability has great driving power to drive the traditional system towards sustainability in the context of Indian manufacturing companies. 
The barrier Information gap (KS1) is the most common hurdle to SSCM implementation in the context of leather industry. Industrial mangers or decision makers of the Bangladeshi leather companies are either unable to implement SSCM practices due to lack of sufficient knowledge or they fail to understand the importance of SSCM practices. Presently awareness on sustainability issues like waste minimization, proper utilization of resource and energy, prevention of pollution, as well as minimization of negative social impact, accident preventions strategy, are not well practiced in the case of leather industry. This finding aligns with previous literature from various countries as for example Muduli et al., (2013) pointed out that information gap can be played as substantial constraint for GSCM initiation for Indian mining industry, Moktadir et al., (2018) believed that awareness of decision makers and customers on sustainability may drive the leather companies towards sustainable manufacturing practices, Govindan et al., (2014b) have tried to evaluate the barriers for GSCM implementation in Indian manufacturing companies and pointed out that information gap still hamper the implementation process. Contradiction of some previous work can be summed up below: Zaabi et al., (2013) did not believe that information gap can act as barriers for Indian manufacturing industry rather than training can help decision makers of Indian mining industry to greening the supply chain, (Rakesh K. Mudgal et al., 2010) tried to modeling the barriers to green supply chain management in the perspective of India and they did not blame that information gap can influence the implementation process, (Sajjad Jalalifar, 2013) reported that information gap can be influenced by other GSCM implementing barriers in the context of Iranian manufacturing industry.

Hoque and Clarke, (2013) reported that leather processing industry is one of the most polluted industrial sectors of Bangladesh. Hence it necessary to adopt cleaner technology based advanced technology to minimize the environmental pollutions. In this study, Lack of cleaner technology (T3) identified as causal driving barriers that means it can influence other effect group barriers. Our findings matched with some previous research on green supply chain, reverse logistics etc. For Example, Wang et al., (2015) investigated the GSCM implementing barriers of food packaging industry in the context of India and claimed that lack of advanced technology hamper the environment greatly. Environmental degradation is largely responsible for lack of advanced technology as reported by many authors (Wang et al., 2015; Mittal and Sangwan, 2014; Chien, 2014; Zhu and Sarkis, 2007). Mudgal et al., (2010) pointed out that cleaner technology help to minimize the creation of pollution and waste in production processes. Liang et al., (2016) reported that cleaner technology can help Chinese biofuel industry to minimize the pollutions for sustainable development. Xia et al., (2015) investigated the internal barriers for automotive parts remanufacturing industry and claimed that without advanced technology, it is impossible to remanufacture automotive parts. Therefore, it is clear that cleaner technology can facilitate the leather processing companies to minimize the water, soil and air pollution greatly and also can help to minimize the negative society impact. Cleaner technology is mandatory for manufacturing process in the developed countries (Subramanian and Gunasekaran, 2015; M.-L. Tseng et al., 2013). Hence, some literature also contradicted our findings as well as existing 
literature. For example, Zaabi et al., (2013) did not consider this barriers for Indian manufacturing industries, Diabat and Govindan, (2011) investigated the drivers to GSCM implementation and they also avoid cleaner technology as a driver for green practices.

The above mentioned literature confirmed that the identified all nine causal barriers may act as crucial driving barriers which can drive all of the influenced barriers simultaneously during implementing SSCM in the leather industry of Bangladesh.

\subsection{Sensitivity Analysis}

Sensitivity analysis is a process to test the robustness of results. For this purpose, a different weighting was assigned to one expert's feedback, while keeping equal weightings for the other experts. This can be done in a number of ways, for example, by changing the level of weightings given to experts or to the various barriers. In this study, we use archetypal sensitivity analysis by assigning separate weightings to experts. For example, first, the weight assigned to Expert 1 was 0.4 , while the other experts were assigned a weight of 0.2 .

For sensitivity analysis, we made four separate total relationship matrices by multiplying each weight assigned to the different experts in response to Table A1, and other similar matrices. After that, average relationship matrices were computed and, finally, the cause-effect relationships among the different barriers were established. The weight assigned for four experts, and the ranking of different barriers during sensitivity analysis, are shown in Tables $\mathbf{1 0}$ and 11.

$<$ Take in Table 10 about here $>$

$<$ Take in Table 11 about here $>$

Therefore, the digraphs obtained from the sensitivity analysis for Expert 1 are shown in Fig. 4. The other digraphs, for Expert 2, Expert 3 and Expert 4, were plotted similarly.

<Take in Fig. 4 about here>

From the digraph above, it is clear that there was no major change in barrier rankings after sensitivity analysis. The same rank order for cause-effect barriers for each expert was obtained, accepting minor rank order variation. Therefore, the sensitivity analysis confirms the robustness of obtained results.

\section{Theoretical and managerial Implications}

This section provides theoretical and practical implications of present study. This research has novel contributions both in cleaner production body of knowledge and in practical fields particularly for an emerging economy.

\subsection{Implications to theoretical knowledge}


It is evident from the results that the identification of the most influential barriers is necessary to ensure sustainable manufacturing practices and sustainable development. Hence, this study contributes to stakeholders' theory which facilitates the stakeholders to minimize the negative environmental, social and economic impact and to enhance the sustainability of supply chains (Sarkis et al., 2011). The stakeholders are those groups of entities that can affect or can be affected by companies or organizations performance. The stakeholders may be the customers, owners, government, society, buyers, media, non-government organizations etc. This study may contribute the theoretical framework by influencing the group of outside stakeholders (like customers, buyers, media, NGO etc.) by realizing the negative impact of social, environmental of the current practices of leather companies supply chains. This outside stakeholders may force leather companies to implement SSCM practices to reduce the negative environmental, social and economic impacts. Internal stakeholders (owners of the leather companies) may also able to realize the importance of sustainable manufacturing practices for the leather companies thus will help decision makers and industrial mangers to design the environmental and socially friendly supply chain networks. Therefore, this study will help to improve the sustainability performance of the leather companies. This observations can motivate the leather companies to incorporate the stakeholders concerns in its existing manufacturing practices which will turn potentially improve the sustainable manufacturing practices.

\subsection{Implications to practice}

The results of this study have important implications for decision makers involved in the implementation of SSCM. From this study, several managerial suggestions were formed. The effect group can easily influenced by the cause group and, therefore, managers should give most attention to causal barriers when implementing SSCM practices in their traditional supply chains. This study will help managers to define the barriers needing greater attention within their industries and to identify which ones are less important. The ranking of cause and effect group barriers can assist managers and decision makers to develop strategic policy during SSCM implementation. The results of this research framework could encourage decision makers and industrial managers to adopt the SSCM practices which are the most important to sustainable development, and have the greatest effect on transforming traditional supply chains. Managers can consider this framework as a benchmark for improving traditional supply chains, leading to improved environmental, social and economic sustainability.

\subsection{Implications to policy}

This study offers several specific policy related implications which may facilitate decision makers and industrial managers to improve the current state of practices towards sustainable development of the leather sector of Bangladesh. The specific polices are presented below:

$\Rightarrow$ Developing customer awareness towards sustainability: This study may help local customers to understand the benefit of green products and the better understanding of local customer 
on green products may create extra force on decision makers and industrial manager to produce environmentally friendly products as a part of SSCM practices in the traditional supply networks. The customers awareness may help decision makers to build some strategic policy to improve the present state of condition,

$\Rightarrow$ Expanding funds and support from top management: Implementing SSCM practices are cost effective decision. Hence, to be more sustainable in the global market, it is necessary to introduce SSCM practices. Therefore, this research will help managers and decision makers to expand more funds and support to implement SSCM practices. This study also may help decision makers to realize the upcoming global trends and help to motivate to implement SSCM practices.

$\Rightarrow$ Initiating training program on sustainability issues: Regulatory authority should initiate training program on sustainability issues to educate supplier, customers and policy makers. Thus will help industrial managers and practitioners to realize the importance of sustainability.

\section{Conclusions, unique contribution and further research scope}

SSCM practices are becoming popular business trend for sustainable development of industrial sector. Companies are trying to implement SSCM practices for business continuity (Chin et al., 2015). Hence, it is not an easy task to implement SSCM in traditional supply chains, because there are numerous barriers. Therefore, the present study attempts to propose a structural model to assess the interrelationships among such barriers which is more relevant to emerging economies since they faces multiple hurdles and are in the early stage of SSCM implementation. The motive behind proposing the structural model to analyze the barriers to SSCM implementation is that no study has yet been conducted on barriers to SSCM implementation in the leather processing industry using a grey DEMATEL approach. The findings revealed that there were nine barriers belong to causal group and eleven in the effect group. Lack of awareness of local customers in green products, lack of commitment from top management, cost of sustainability and economic conditions, lack of eco-literacy amongst supply chain partners, absence of society pressure, lack of training and education about sustainability, information gap, and lack of cleaner technology seemed to be the most important causal driving barriers to SSCM initiation in the studied supply chain. Lack of reverse logistics practices and outdated machinery seemed to be the most influential barriers. This means that other barriers can easily influence those barriers, and that the improvement of other barriers will directly influence them. Therefore, this study may help managers and planners identify the most influential SSCM implementation barriers. This highlights the steps necessary to eradicate them. The main contributions of this study can be summarised as follows.

This study initially contributed existing literature by identifying 35 barriers to SSCM implementation and finally selected 20 barriers; nine of them belong to causal group and eleven in the effect group which was examined by the grey DEMATEL method. The 
causal barriers may act as crucial driving barriers for sustainable development in an emerging economy.

This study is a unique one in the sense that no previous study has been conducted in the context of leather industry supply chains. The leather industry is a second most polluted industrial sector as well as export earners of Bangladesh and thus needs SSCM implementation.

The proposed research framework is a unique application and decision makers can use as a benchmark in the context of Bangladesh.

It is noted that the grey-based DEMATEL approach is a very effective method for evaluating the contextual relationships among barriers in an imprecise environment. However, this method is largely depends on experts' feedback. Therefore, it is recommended that experts' feedback should be collected carefully. Another limitation is that we only consider twenty barriers to develop the SSCM implementing framework. Further, this research work was limited in the number of barriers it could analyze due to the complexity of the model.

Our expectation is that this research will be helpful to evaluate the contextual relationship among barriers to SSCM implementation in other industries, such as the clothing, footwear, and polymer, food processing, mining, chemical, and pharmaceutical industries of Bangladesh. All of these industries have harmful effects on environment and society. Other industrial sectors may need to consider greater numbers of relevant barriers in their analyses. In future, other multicriteria decision-making tools, like Fuzzy-AHP, Fuzzy-VIKOR, Fuzzy-DEMATEL, ISM and TISM, could be used to evaluate the most influential barriers to the adoption of SSCM practices.

Acknowledgements: The authors acknowledge support from the Bangladesh University of Engineering and Technology (BUET), and a number of local leather processing factories.

\section{References:}

Ali, S.M., Arafin, A., Moktadir, M.A., Rahman, T., Zahan, N., 2017. Barriers to Reverse Logistics in the Computer Supply Chain Using Interpretive Structural Model. Glob. J. Flex. Syst. Manag. 1-16. doi:10.1007/s40171-017-0176-2

Ametepey, O., Aigbavboa, C., Ansah, K., 2015. Barriers to Successful Implementation of Sustainable Construction in the Ghanaian Construction Industry. Procedia Manuf. 3, 1682-1689. doi:10.1016/j.promfg.2015.07.988

Andiç, E., Yurt, Ö., Baltacioğlu, T., 2012. Green supply chains: Efforts and potential applications for the Turkish market. Resour. Conserv. Recycl. 58, 50-68. doi:10.1016/j.resconrec.2011.10.008 
Arikan, R., Dağdeviren, M., Kurt, M., 2013. Arikan, R., Dağdeviren, M., \& Kurt, M. (2013). A fuzzy multi-attribute decision making model for strategic risk assessment. International Journal of Computational Intelligence Systems, 6(3), 487-502. Int. J. Comput. Intell. Syst. 6, 487-502. doi:10.1080/18756891.2013.781334

Asad, M.M., Mohammadi, V., Shirani, M., 2016. Modeling Flexibility Capabilities of IT-based Supply Chain, Using a Grey-based \{DEMATEL\} Method. Procedia Econ. Financ. 36, 220-231. doi:http://dx.doi.org/10.1016/S2212-5671(16)30033-8

Bai, C., Kusi-Sarpong, S., Sarkis, J., 2017. An implementation path for green information technology systems in the Ghanaian mining industry. J. Clean. Prod. 164, 1105-1123. doi:10.1016/j.jclepro.2017.05.151

Barve, A., Muduli, K., 2013. Modelling the challenges of green supply chain management practices in Indian mining industries. J. Manuf. Technol. Manag. 24, 1102-1122. doi:10.1108/JMTM-09-20110087

Baumgartner, R.J., Korhonen, J., 2010. Strategic thinking for sustainable development. Sustain. Dev. 18, 71-75. doi:10.1002/sd.452

Bhanot, N., Rao, P.V., Deshmukh, S.G., 2017. An integrated approach for analysing the enablers and barriers of sustainable manufacturing. J. Clean. Prod. 142, 4412-4439. doi:10.1016/j.jclepro.2016.11.123

Bhanot, N., Rao, P.V., Deshmukh, S.G., 2015. Enablers and barriers of sustainable manufacturing: Results from a survey of researchers and industry professionals, in: Procedia CIRP. pp. 562-567. doi:10.1016/j.procir.2015.01.036

Bouzon, M., Govindan, K., Rodriguez, C.M.T., 2016a. Evaluating barriers for reverse logistics implementation under a multiple stakeholders' perspective analysis using grey decision making approach. Resour. Conserv. Recycl. doi:10.1016/j.resconrec.2016.11.022

Bouzon, M., Govindan, K., Rodriguez, C.M.T., Campos, L.M.S., 2016b. Identification and analysis of reverse logistics barriers using fuzzy Delphi method and AHP. Resour. Conserv. Recycl. 108, 182197. doi:10.1016/j.resconrec.2015.05.021

Brécard, D., Hlaimi, B., Lucas, S., Perraudeau, Y., Salladarré, F., 2009. Determinants of demand for green products: An application to eco-label demand for fish in Europe. Ecol. Econ. 69, 115-125. doi:10.1016/j.ecolecon.2009.07.017

Campbell, J.Y., 2000. Strategic asset allocation: Portfolio choice for long-term investors. NBER Report. 8-12. doi:10.1111/1468-0297.13917

Carter, C.R., Easton, P.L., 2011. Sustainable supply chain management: evolution and future directions. Int. J. Phys. Distrib. Logist. Manag. 41, 46-62. doi:10.1108/09600031111101420

Carter, C.R., Rogers, D.S., 2008. A framework of sustainable supply chain management: moving toward new theory. Int. J. Phys. Distrib. Logist. Manag. 38, 360-387. doi:10.1108/09600030810882816

Chan, H.K., 2007. A pro-active and collaborative approach to reverse logistics - a case study. Prod. Plan. Control 18, 350-360. doi:10.1080/09537280701318736

Chen, Y.S., Lai, S.B., Wen, C.T., 2006. The influence of green innovation performance on corporate 
advantage in Taiwan. J. Bus. Ethics 67, 331-339. doi:10.1007/s10551-006-9025-5

Chien, M.-K., 2014. Influences of green supply chain management practices on organizational sustainable performance. Int. J. Environ. Monit. Prot. 1, 12-23.

Chilamkurti, N., Zeadally, S., Mentiplay, F., 2009. Green networking for major components of information communication technology systems. Eurasip J. Wirel. Commun. Netw. 2009. doi:10.1155/2009/656785

Chin, T.A., Tat, H.H., Sulaiman, Z., 2015. Green supply chain management, environmental collaboration and sustainability performance, in: Procedia CIRP. pp. 695-699. doi:10.1016/j.procir.2014.07.035

Cowan, N., 2008. What are the differences between long-term, short-term, and working memory? Prog. Brain Res. 169, 323-38. doi:10.1016/S0079-6123(07)00020-9

de Camargo Fiorini, P., Jabbour, C.J.C., 2017. Information systems and sustainable supply chain management towards a more sustainable society: Where we are and where we are going. Int. J. Inf. Manage. doi:10.1016/j.ijinfomgt.2016.12.004

Diabat, A., Govindan, K., 2011. An analysis of the drivers affecting the implementation of green supply chain management. Resour. Conserv. Recycl. 55, 659-667. doi:10.1016/j.resconrec.2010.12.002

Diabat, A., Kannan, D., Mathiyazhagan, K., 2014. Analysis of enablers for implementation of sustainable supply chain management - A textile case. J. Clean. Prod. 83, 391-403. doi:10.1016/j.jclepro.2014.06.081

Dong, S., Luo, S., 2006. Modified grey-level models for active shape model training. Conf. Proc. IEEE Eng. Med. Biol. Soc. 1, 3791-3794. doi:10.1109/IEMBS.2006.260326

Dou, Y., Sarkis, J., Bai, C., 2014. Government green procurement: a Fuzzy-DEMATEL analysis of barriers, in: Supply Chain Management under Fuzziness. Springer Berlin Heidelberg, pp. 567-589. doi:10.1007/978-3-642-53939-8_24

Dubey, R., Gunasekaran, A., 2015. Shortage of sustainable supply chain talent: an industrial training framework. Ind. Commer. Train. 47, 86-94. doi:10.1108/ICT-08-2014-0052

Egilmez, G., Kucukvar, M., Tatari, O., Bhutta, M.K.S., 2014. Supply chain sustainability assessment of the U.S. food manufacturing sectors: A life cycle-based frontier approach. Resour. Conserv. Recycl. 82, 8-20. doi:10.1016/j.resconrec.2013.10.008

Eltayeb, T., Zailani, S., 2009. Going green through green supply chain initiatives towards environmental sustainability. Oper. Supply Chain ... 2, 93-110.

Esfahbodi, A., Zhang, Y., Watson, G., 2016a. Sustainable supply chain management in emerging economies: Trade-offs between environmental and cost performance. Int. J. Prod. Econ. 1-17. doi:10.1016/j.ijpe.2016.02.013

Esfahbodi, A., Zhang, Y., Watson, G., 2016b. Sustainable supply chain management in emerging economies: Trade-offs between environmental and cost performance. Int. J. Prod. Econ. 181, 350366. doi:10.1016/j.ijpe.2016.02.013

$\mathrm{Fu}, \mathrm{C}$., Zheng, J., Zhao, J., Xu, W., 2001. Application of grey relational analysis for corrosion failure of oil tubes. Corros. Sci. 43, 881-889. doi:10.1016/S0010-938X(00)00089-5 
Fu, X., Zhu, Q., Sarkis, J., 2012. Evaluating green supplier development programs at a telecommunications systems provider. Int. J. Prod. Econ. 140, 357-367. doi:10.1016/j.ijpe.2011.08.030

Gandhi, S., Mangla, S.K., Kumar, P., Kumar, D., 2015. Evaluating factors in implementation of successful green supply chain management using DEMATEL: A case study. Int. Strateg. Manag. Rev. 3, 96-109. doi:10.1016/j.ism.2015.05.001

Gaziulusoy, A.I., Boyle, C., McDowall, R., 2013. System innovation for sustainability: A systemic double-flow scenario method for companies. J. Clean. Prod. 45, 104-116. doi:10.1016/j.jclepro.2012.05.013

Giunipero, L.C., Hooker, R.E., Denslow, D., 2012. Purchasing and supply management sustainability: Drivers and barriers. J. Purch. Supply Manag. 18, 258-269. doi:10.1016/j.pursup.2012.06.003

González-Torre, P., Álvarez, M., Sarkis, J., Adenso-Díaz, B., 2010. Barriers to the Implementation of Environmentally Oriented Reverse Logistics: Evidence from the Automotive Industry Sector P. González-Torre et al. Barriers to Implementation of Reverse Logistics. Br. J. Manag. 21, 889-904. doi:10.1111/j.1467-8551.2009.00655.x

Gosling, J., Jia, F., Gong, Y., Brown, S., 2017. The role of supply chain leadership in the learning of sustainable practice: Toward an integrated framework. J. Clean. Prod. 140, 239-250. doi:10.1016/j.jclepro.2016.09.101

Govindan, K., 2017. Sustainable consumption and production in the food supply chain: A conceptual framework. Int. J. Prod. Econ. in press, 1-14. doi:10.1016/j.ijpe.2017.03.003

Govindan, K., Azevedo, S.G., Carvalho, H., Cruz-Machado, V., 2014a. Impact of supply chain management practices on sustainability. J. Clean. Prod. 85, 212-225. doi:10.1016/j.jclepro.2014.05.068

Govindan, K., Kaliyan, M., Kannan, D., Haq, A.N., 2014b. Barriers analysis for green supply chain management implementation in Indian industries using analytic hierarchy process. Int. J. Prod. Econ. 147, 555-568. doi:10.1016/j.ijpe.2013.08.018

Govindan, K., Khodaverdi, R., Vafadarnikjoo, A., 2016. A grey DEMATEL approach to develop thirdparty logistics provider selection criteria. Ind. Manag. Data Syst. 116, 690-722. doi:10.1108/IMDS05-2015-0180

Govindan, K., Popiuc, M.N., Diabat, A., 2013. Overview of coordination contracts within forward and reverse supply chains. J. Clean. Prod. 47, 319-334. doi:10.1016/j.jclepro.2013.02.001

Green, K.W., Pamela, J., Jeramy, J.Z., Vikram, M., Kenneth W., G., Zelbst, P.J., Meacham, J., Bhadauria, V.S., 2013. Green supply chain management practices: impact on performance. Supply Chain Manag. An Int. J. 17, 20-305. doi:10.1108/13598541211227126

Grutter, J.M., Egler, H.P., 2004. From cleaner production to sustainable industrial production modes. J. Clean. Prod. 12, 249-256. doi:10.1016/S0959-6526(03)00094-5

Harms, D., 2011. Environmental Sustainability and Supply Chain Management - A Framework of Cross-Functional Integration and Knowledge Transfer. J. Environ. Sustain. 1, 1-23 / 21. doi:10.14448/jes.01.0009 
Henriques, I., Sadorsky, P., 1996. The Determinants of an Environmentally Responsive Firm: An Empirical Approach. J. Environ. Econ. Manage. 30, 381-395. doi:10.1006/jeem.1996.0026

Hillary, R., 2004. Environmental management systems and the smaller enterprise, in: Journal of Cleaner Production. pp. 561-569. doi:10.1016/j.jclepro.2003.08.006

Hong, P., Kwon, H.-B., Roh, J.J., 2009. Implementation of strategic green orientation in supply chain: An empirical study of manufacturing firms. Eur. J. Innov. Manag. 12, 512-532. doi:10.1108/14601060910996945

Hoque, A., Clarke, A., 2013. Greening of industries in Bangladesh: Pollution prevention practices. J. Clean. Prod. 51, 47-56. doi:10.1016/j.jclepro.2012.09.008

Hsu, C.-W., Kuo, T.-C., Chen, S.-H., Hu, A.H., 2013. Using DEMATEL to develop a carbon management model of supplier selection in green supply chain management. J. Clean. Prod. 56, 164-172. doi:10.1016/j.jclepro.2011.09.012

Jabbour, C.J.C., 2013a. Environmental training in organisations: From a literature review to a framework for future research. Resour. Conserv. Recycl. doi:10.1016/j.resconrec.2012.12.017

Jabbour, C.J.C., De Sousa Jabbour, A.B.L., 2016. Green Human Resource Management and Green Supply Chain Management: Linking two emerging agendas. J. Clean. Prod. 112, 1824-1833. doi:10.1016/j.jclepro.2015.01.052

Jabbour, A.B.L.D.S., Frascareli, F.C.D.O., Jabbour, C.J.C., 2015. Green supply chain management and firms' performance: Understanding potential relationships and the role of green sourcing and some other green practices. Resour. Conserv. Recycl. 104, 366-374. doi:10.1016/j.resconrec.2015.07.017

Jabbour, C.J.C., 2015. Environmental training and environmental management maturity of Brazilian companies with ISO14001: Empirical evidence. J. Clean. Prod. 96, 331-338. doi:10.1016/j.jclepro.2013.10.039

Jabbour, C.J.C., 2010. Non-linear pathways of corporate environmental management: A survey of ISO 14001-certified companies in Brazil. J. Clean. Prod. 18, 1222-1225. doi:10.1016/j.jclepro.2010.03.012

Jabbour, C.J.C., Jabbour, A.B.L. de S., 2016. Demystifying the challenges and barriers to manage, develop, and transfer clean and green technologies in Brazilian academic research groups: Some empirical evidence. Int. J. Green Energy 13, 907-910. doi:10.1080/15435075.2015.1109515

Jabbour, C.J.C., Maria Da Silva, E., Paiva, E.L., Almada Santos, F.C., 2012. Environmental management in Brazil: Is it a completely competitive priority? J. Clean. Prod. 21, 11-22. doi:10.1016/j.jclepro.2011.09.003

Jabbour, C.J.C., Santos, F.C.A., Fonseca, S.A., Nagano, M.S., 2013b. Green teams: Understanding their roles in the environmental management of companies located in Brazil. J. Clean. Prod. doi:10.1016/j.jclepro.2012.09.018

Jack, E.P., Powers, T.L., Skinner, L., 2010. Reverse logistics capabilities: antecedents and cost savings. Int. J. Phys. Distrib. Logist. Manag. 40, 228-246. doi:10.1108/09600031011035100 
Jayal, A.D., Badurdeen, F., Dillon, O.W., Jawahir, I.S., 2010. Sustainable manufacturing: Modeling and optimization challenges at the product, process and system levels. CIRP J. Manuf. Sci. Technol. 2, 144-152. doi:10.1016/j.cirpj.2010.03.006

Jayant, A., Azhar, M., 2014. Analysis of the barriers for implementing green supply chain management (GSCM) Practices: An Interpretive Structural Modeling (ISM) Approach, in: Procedia Engineering. pp. 2157-2166. doi:10.1016/j.proeng.2014.12.459

Jeng, D.J.F., Tzeng, G.H., 2012. Social influence on the use of Clinical Decision Support Systems: Revisiting the Unified Theory of Acceptance and Use of Technology by the fuzzy DEMATEL technique. Comput. Ind. Eng. 62, 819-828. doi:10.1016/j.cie.2011.12.016

Jenkin, T.A., Webster, J., McShane, L., 2011. An agenda for "Green" information technology and systems research. Inf. Organ. 21, 17-40. doi:10.1016/j.infoandorg.2010.09.003

Ji, L., Huang, J., Liu, Z., Zhu, H., Cai, Z., 2012. The effects of employee training on the relationship between environmental attitude and firms' performance in sustainable development. Int. J. Hum. Resour. Manag. 23, 2995-3008. doi:10.1080/09585192.2011.637072

Johannessen, J.-A., Olsen, B., 2003. Knowledge management and sustainable competitive advantages: The impact of dynamic contextual training. Int. J. Inf. Manage. 23, 277-289. doi:10.1016/S02684012(03)00050-1

Ju-Long, D., 1982. Control problems of grey systems. Syst. Control Lett. 1, 288-294. doi:10.1016/S01676911(82)80025-X

Julong, D., 1989. Introduction to Grey System Theory. J. Grey Syst. 1, 1-24.

Junjie, X., Zhong, W., Hongyan, M., Jing, G., 2007. Implementing ISO14000 and promoting sustainable development of manufacturing industry, in: PROCEEDINGS OF THE 4TH INTERNATIONAL CONFERENCE ON INNOVATION \& MANAGEMENT, VOLS I AND II. pp. 1751-1755.

Khidir, T. Al, Zailani, S., 2009. Going Green in Supply Chain Towards Environmental Sustainability. Glob. J. Environ. Res. 3, 246-251.

Koho, M., Tapaninaho, M., Torvinen, S., 2011. Towards Sustainable Development and Sustainable Production in Finnish Manufacturing Industry. 4th Int. Conf. Chang. Agil. Reconfigurable Virtual Prod. (CARV2011), Montr. Canada 2011 422-427.

Kose, E., Kabak, M., Aplak, H., 2013. Grey theory based $\{\mathrm{MCDM}\}$ procedure for sniper selection problem. Grey Syst. 3, 35-45. doi:http://dx.doi.org/10.1108/20439371311293688

Kulatunga, A.K., Jayatilaka, P. R. Jayawickrama, M., 2013. Drivers and barriers to implement sustainable manufacturing concepts in Sri Lankan manufacturing sector, in: 11th Global Conference on Sustainable Manufacturing. pp. 171-176. doi:10.13140/2.1.2952.1927

Kusi-Sarpong, S., Sarkis, J., Wang, X., 2016. Assessing green supply chain practices in the Ghanaian mining industry: A framework and evaluation. Int. J. Prod. Econ. 181, 325-341. doi:10.1016/j.ijpe.2016.04.002

Le Bourhis, F., Kerbrat, O., Hascoet, J.-Y., Mognol, P., 2013. Sustainable manufacturing: evaluation and modeling of environmental impacts in additive manufacturing. Int. J. Adv. Manuf. Technol. 69, 1927-1939. doi:10.1007/s00170-013-5151-2 
Lee, S.M., Tae Kim, S., Choi, D., 2012. Green supply chain management and organizational performance. Ind. Manag. Data Syst. 112, 1148-1180. doi:10.1108/02635571211264609

Li, G.-D., Yamaguchi, D., Nagai, M., 2007. A grey-based decision-making approach to the supplier selection problem. Math. Comput. Model. 46, 573-581. doi:10.1016/j.mcm.2006.11.021

Li, Y., 2014. Environmental innovation practices and performance: Moderating effect of resource commitment. J. Clean. Prod. 66, 450-458. doi:10.1016/j.jclepro.2013.11.044

Liang, H., Ren, J., Gao, Z., Gao, S., Luo, X., Dong, L., Scipioni, A., 2016. Identification of critical success factors for sustainable development of biofuel industry in China based on grey decisionmaking trial and evaluation laboratory (DEMATEL). J. Clean. Prod. 131, 500-508. doi:10.1016/j.jclepro.2016.04.151

Lieder, M., Rashid, A., 2016. Towards circular economy implementation: A comprehensive review in context of manufacturing industry. J. Clean. Prod. doi:10.1016/j.jclepro.2015.12.042

Lin, C.-T., Hwang, S.-N., Chan, C.-H., 2004. Grey number for ahp model: an application of grey relational analysis, in: Proceedings of the 2004 IEEE International Conference on Networking, Sensing and Control. pp. 226-230. doi:10.1109/ICNSC.2004.1297439

Lin, R.-J., 2011. Using fuzzy DEMATEL to evaluate the green supply chain management practices. J. Clean. Prod. 40, 32-39. doi:10.1016/j.jclepro.2011.06.010

Lin, R., Tan, K., Geng, Y., 2013. Market demand, green product innovation, and firm performance: evidence from Vietnam motorcycle industry. J. Clean. Prod. 40, 101-107. doi:10.1016/j.jclepro.2012.01.001

Liu, S., Forrest, J., Yang, Y., 2011. A brief introduction to grey systems theory, in: Proceedings of 2011 IEEE International Conference on Grey Systems and Intelligent Services, GSIS'11 - Joint with the 15th WOSC International Congress on Cybernetics and Systems. pp. 1-9. doi:10.1109/GSIS.2011.6044018

Liu, S., Kasturiratne, D., Moizer, J., 2012. A hub-and-spoke model for multi-dimensional integration of green marketing and sustainable supply chain management. Ind. Mark. Manag. 41, 581-588. doi:10.1016/j.indmarman.2012.04.005

Luthra, S., Govindan, K., Kumar, S., 2017. Structural model for sustainable consumption and production adoption - A grey-DEMATEL based approach. "Resources, Conserv. Recycl. 125, 198-207. doi:10.1016/j.resconrec.2017.02.018

Luthra, S., Kumar, V., Kumar, S., Haleem, A., 2011. Barriers to implement green supply chain management in automobile industry using interpretive structural modeling technique: An Indian perspective. J. Ind. Eng. Manag. 4, 231-257. doi:10.3926/jiem..v4n2.p231-257

Luzio, J.P.P., Lemke, F., 2013. Exploring green consumers product demands and consumption processes; The case of Portuguese green consumers. Eur. Bus. Rev. 25, 281-300. doi:10.1108/09555341311314825

MacDonald, J.P., 2005. Strategic sustainable development using the ISO 14001 Standard. J. Clean. Prod. 13, 631-643. doi:10.1016/j.jclepro.2003.06.001

Majid, K.A., Russell, C.A., 2015. Giving green a second thought: Modeling the value retention of green 
products in the secondary market. J. Bus. Res. 68, 994-1002. doi:10.1016/j.jbusres.2014.10.001

Mangla, S.K., Govindan, K., Luthra, S., 2017. Prioritizing the barriers to achieve sustainable consumption and production trends in supply chains using fuzzy Analytical Hierarchy Process. J. Clean. Prod. 151, 509-525. doi:10.1016/j.jclepro.2017.02.099

Mani, V., Gunasekaran, A., Papadopoulos, T., Hazen, B., Dubey, R., 2016. Supply chain social sustainability for developing nations: Evidence from india. Resour. Conserv. Recycl. 111, 42-52. doi:10.1016/j.resconrec.2016.04.003

Marcon, A., de Medeiros, J.F., Ribeiro, J.L.D., 2017. Innovation and environmentally sustainable economy: Identifying the best practices developed by multinationals in Brazil. J. Clean. Prod. 160, 83-97. doi:10.1016/j.jclepro.2017.02.101

Mathivathanan, D., Kannan, D., Haq, A.N., 2017. Sustainable supply chain management practices in Indian automotive industry: A multi-stakeholder view. Resour. Conserv. Recycl. doi:10.1016/j.resconrec.2017.01.003

Mathiyazhagan, K., Govindan, K., NoorulHaq, A., Geng, Y., 2013. An ISM approach for the barrier analysis in implementing green supply chain management. J. Clean. Prod. 47, 283-297. doi:10.1016/j.jclepro.2012.10.042

Min, H., Galle, W.P., 2001. Green purchasing practices of US firms. Int. J. Oper. Prod. Manag. 21, 12221238. doi:10.1108/EUM0000000005923

Mittal, V.K., Egede, P., Herrmann, C., Sangwan, K.S., 2013. Comparison of drivers and barriers to green manufacturing: A case of India and Germany. Re-Engineering Manuf. Sustain. - Proc. 20th CIRP Int. Conf. Life Cycle Eng. 723-728. doi:10.1007/978-981-4451-48-2_118

Mittal, V.K., Sangwan, K.S., 2014. Prioritizing drivers for green manufacturing: Environmental, social and economic perspectives, in: Procedia CIRP. pp. 135-140. doi:10.1016/j.procir.2014.06.038

Moktadir, A., Rahman, T., Rahman, H., Ali, S.M., Paul, S.K., 2018. Drivers to sustainable manufacturing practices and circular economy: a perspective of leather industries in Bangladesh. J. Clean. Prod. 174, 1366-1380. doi:10.1016/j.jclepro.2017.11.063

Mol, M.J., Birkinshaw, J., 2009. The sources of management innovation: When firms introduce new management practices. J. Bus. Res. 62, 1269-1280. doi:10.1016/j.jbusres.2009.01.001.

Mudgal, R.K., Shankar, R., Talib, P., Raj, T., 2010. Modelling the barriers of green supply chain practices: An Indian perspective. Int. J. Logist. Syst. Manag. 7, 81-107. doi:10.1504/IJLSM.2010.033891

Muduli, K., Govindan, K., Barve, A., Geng, Y., 2013. Barriers to green supply chain management in Indian mining industries: A graph theoretic approach. J. Clean. Prod. 47, 335-344. doi:10.1016/j.jclepro.2012.10.030

Nawrocka, D., Brorson, T., Lindhqvist, T., 2009. ISO 14001 in environmental supply chain practices. J. Clean. Prod. 17, 1435-1443. doi:10.1016/j.jclepro.2009.05.004

Nejati, M., Rabiei, S., Chiappetta Jabbour, C.J., 2017. Envisioning the invisible: Understanding the synergy between green human resource management and green supply chain management in manufacturing firms in Iran in light of the moderating effect of employees' resistance to change. J. 
Clean. Prod. 168, 163-172. doi:10.1016/j.jclepro.2017.08.213

Nidumolu, R., Prahalad, C.K., Rangaswami, M.R., 2009. Why sustainability is now the key driver of innovation. Harv. Bus. Rev. 87. doi:10.1109/EMR.2013.6601104

Nordin, N., Ashari, H., Hassan, M.G., 2014. Drivers and barriers in sustainable manufacturing implementation in Malaysian manufacturing firms, in: IEEE International Conference on Industrial Engineering and Engineering Management. pp. 687-691. doi:10.1109/IEEM.2014.7058726

Nowosielski, R., 2007. Sustainable technology as a basis of cleaner production. J. Achiev. ... 20, 527530.

Özdemır, A., Tüysüz, F., 2015. A Grey-based DEMATEL approach for analyzing the strategies of universities: A case of Turkey, in: 6th International Conference on Modeling, Simulation, and Applied Optimization. IEEE, Istanbul, Turkey, pp. 1-6. doi:10.1109/ICMSAO.2015.7152266

Pagell, M., Wu, Z.H., 2009. Building a more complete theory of sustainable supply chain management using case studies of 10 exemplars. J. Supply Chain Manag. 45, 37-56. doi:10.1111/j.1745493X.2009.03162.x

Parker, C.M., Redmond, J., Simpson, M., 2009. A review of interventions to encourage SMEs to make environmental improvements, in: Environment and Planning C: Government and Policy. pp. 279301. doi:10.1068/c0859b

Paul, H.L., Antunes, A.P.M., Covington, A.D., Evans, P., Phillips, P.S., 2013. Bangladeshi Leather Industry: An Overview of Recent Sustainable Developments. SLTC J. 97, 25-32. doi:10.1016/S0011-9164(04)00193-6

Perron, G.M., 2005. Barriers to Environmental Performance Improvements in Canadian SMEs. ... , Canada.

Pokharel, S., Mutha, A., 2009. Perspectives in reverse logistics: A review. Resour. Conserv. Recycl. doi:10.1016/j.resconrec.2008.11.006

Prakash, C., Barua, M.K., 2015. Integration of AHP-TOPSIS method for prioritizing the solutions of reverse logistics adoption to overcome its barriers under fuzzy environment. J. Manuf. Syst. 37, 599-615. doi:10.1016/j.jmsy.2015.03.001

Qian, L., Soopramanien, D., 2015. Incorporating heterogeneity to forecast the demand of new products in emerging markets: Green cars in China. Technol. Forecast. Soc. Change 91, 33-46. doi:10.1016/j.techfore.2014.01.008

Raci, V., Shankar, R., 2005. Analysis of interactions among the barriers of reverse logistics. Technol. Forecast. Soc. Change 72, 1011-1029. doi:10.1016/j.techfore.2004.07.002

Rajesh, R., Ravi, V., 2017. Analyzing drivers of risks in electronic supply chains: a grey???DEMATEL approach. Int. J. Adv. Manuf. Technol. 1-19. doi:10.1007/s00170-017-0118-3

Rajesh, R., Ravi, V., 2015. Modeling enablers of supply chain risk mitigation in electronic supply chains: A Grey-DEMATEL approach. Comput. Ind. Eng. 87, 126-139. doi:10.1016/j.cie.2015.04.028

Rauer, J., Kaufmann, L., 2015. Mitigating external barriers to implementing green supply chain management: A grounded theory investigation of green-tech companies' rare earth metals supply 
chains. J. Supply Chain Manag. 51, 65-88. doi:10.1111/jscm.12063

Raut, R.D., Narkhede, B., Gardas, B.B., 2017. To identify the critical success factors of sustainable supply chain management practices in the context of oil and gas industries: ISM approach. Renew. Sustain. Energy Rev. 68, 33-47. doi:10.1016/j.rser.2016.09.067

Revell, A., Rutherfoord, R., 2003. UK environmental policy and the small firm: Broadening the focus. Bus. Strateg. Environ. 12, 26-35. doi:10.1002/bse.347

Rowe, W.G., Nejad, M.H., 2009. Strategic Leadership: Short-Term Stability and Long-Term Viability. Ivey Bus. J. September/, 12.

Sadaghiani, S., Ahmad, K.W., Rezaei, J., Tavasszy, L., 2015. Evaluation of external forces affecting supply chain sustainability in oil and gas industry using Best Worst Method, in: Gas and Oil Conference (MedGO), 2015 International Mediterranean. IEEE, Mechref, Lebanon. doi:10.1109/MedGO.2015.7330322

Sajjad Jalalifar, K.F.H., 2013. Application of DEMATEL Method for Evaluation of the Effective Barriers in GSCM implementation. New York Sci. J. 6, 77-83.

Sandholm, L., 2005. Strategic plan for sustainable excellence. Total Qual. Manag. Bus. Excell. 16, 10611068. doi:10.1080/14783360500163284

Sandhu, S.S., Rawal, A., Kaur, P., Gupta, N., 2012. Major components associated with green networking in information communication technology systems, in: 2012 International Conference on Computing, Communication and Applications, ICCCA 2012. doi:10.1109/ICCCA.2012.6179233

Santos, F.M., Eisenhardt, K.M., 2005. Organizational boundaries and theories of organization. Organ. Sci. 16, 491-508. doi:10.1287/orsc.1050.0152

Sarkis, J., 2012. A boundaries and flows perspective of green supply chain management. Supply Chain Manag. An Int. J. 17, 202-216. doi:10.1108/13598541211212924

Sarkis, J., Helms, M.M., Hervani, A.A., 2010. Reverse logistics and social sustainability. Corp. Soc. Responsib. Environ. Manag. 17, 337-354. doi:10.1002/csr.220

Sarkis, J., Zhu, Q., Lai, K., 2011. An organizational theoretic review of green supply chain management literature. Int. J. Prod. Econ. 130, 1-15. doi:10.1016/j.ijpe.2010.11.010

Seuring, S., Müller, M., 2008. Core issues in sustainable supply chain management - A Delphi study. Bus. Strateg. Environ. 17, 455-466. doi:10.1002/bse.607

Shao, J., Taisch, M., Ortega-Mier, M., 2016. A grey-DEcision-MAking Trial and Evaluation Laboratory (DEMATEL) analysis on the barriers between environmentally friendly products and consumers: Practitioners' viewpoints on the European automobile industry. J. Clean. Prod. 112, 3185-3194. doi:10.1016/j.jclepro.2015.10.113

Sharifzadegan, M.H., Gollar, P.J., Azizi, H., 2011. Assessing the strategic plan of Tehran by sustainable development approach, using the method of "strategic Environmental Assessment (SEA)," in: Procedia Engineering. pp. 186-195. doi:10.1016/j.proeng.2011.11.2003

Shi, L., Wu, K.J., Tseng, M.L., 2017. Improving corporate sustainable development by using an interdependent closed-loop hierarchical structure. Resour. Conserv. Recycl. 119, 24-35. 
doi:10.1016/j.resconrec.2016.08.014

Shieh, J.-I., Wu, H.-H., Huang, K.-K., 2010. A DEMATEL method in identifying key success factors of hospital service quality. Knowledge-Based Syst. 23, 277-282. doi:10.1016/j.knosys.2010.01.013

Shrivastava, P., 1995. THE ROLE OF CORPORATIONS IN ACHIEVING ECOLOGICAL SUSTAINABILITY. Acad. Manag. Rev. 20, 936-960. doi:10.5465/AMR.1995.9512280026

Stenberg, A.-C., 2007. Green ideas travelling across organizational boundaries. Build. Res. Inf. 35, 501513. doi:10.1080/09613210601132603

Su, C.-M., Horng, D.-J., Tseng, M.-L., Chiu, A.S.F., Wu, K.-J., Chen, H.-P., 2015. Improving sustainable supply chain management using a novel hierarchical grey-DEMATEL approach. J. Clean. Prod. 134, 469-481. doi:10.1016/j.jclepro.2015.05.080

Subramanian, N., Gunasekaran, A., 2015. Cleaner supply-chain management practices for twenty-firstcentury organizational competitiveness: Practice-performance framework and research propositions. Int. J. Prod. Econ. 164, 216-233. doi:10.1016/j.ijpe.2014.12.002

Sumrit, D., Anuntavoranich, P., 2013. Using DEMATEL Method to Analyze the Causal Relations on Technological Innovation Capability Evaluation Factors in Thai Technology-Based Firms. Int. Trans. J. Eng. Manag. Appl. Sci. Technol. 4, 81-103.

Tay, M.Y., Rahman, A.A., Aziz, Y.A., Sidek, S., 2015. A Review on Drivers and Barriers towards Sustainable Supply Chain Practices. Int. J. Soc. Sci. Humanit. 5, 892-897. doi:10.7763/IJSSH.2015.V5.575

Technical Report, 2013. Leather Sector Includes a Value Chain Analysis and Proposed Action Plans. Dhaka, Bangladesh.

Theyel, G., 2000. Management Practices for Environmental Innovation and Performance. Int. J. Oper. Prod. Manag. 20, 249-266. doi:10.1108/01443570010304288

Tseng, M.-L., Chiu, (Anthony) Shun Fung, Tan, R.R., Siriban-Manalang, A.B., 2013. Sustainable consumption and production for Asia: sustainability through green design and practice. J. Clean. Prod. 40, 1-5. doi:10.1016/j.jclepro.2012.07.015

Tseng, M.L., Wang, R., Chiu, A.S.F., Geng, Y., Lin, Y.H., 2013. Improving performance of green innovation practices under uncertainty. J. Clean. Prod. 40, 71-82. doi:10.1016/j.jclepro.2011.10.009

Turker, D., Altuntas, C., 2014. Sustainable supply chain management in the fast fashion industry: An analysis of corporate reports. Eur. Manag. J. 32, 837-849. doi:10.1016/j.emj.2014.02.001

Teixeira, A.A., Jabbour, C.J.C., Jabbour, A.B.L. de S., Latan, H., Oliveira, J.H.C. de, 2016. Green training and green supply chain management: Evidence from Brazilian firms. J. Clean. Prod. 116, 170-176. doi:10.1016/j.jclepro.2015.12.061

Vachon, S., 2007. Green supply chain practices and the selection of environmental technologies. Int. J. Prod. Res. 45, 4357-4379. doi:10.1080/00207540701440303

Vachon, S., Klassen, R.D., 2007. Supply chain management and environmental technologies: the role of integration. Int. J. Prod. Res. 45, 401-423. doi:10.1080/00207540600597781

Vachon, S., Klassen, R.D., 2006. Extending green practices across the supply chain: The impact of 
upstream and downstream integration, International Journal of Operations \& Production Management. doi:10.1108/01443570610672248

Vafadarnikjoo, A., 2014. Corrigendum to "Using fuzzy DEMATEL to evaluate the green supply chain management practices” J. Clean. Prod. 82, 232. doi:10.1016/j.jclepro.2014.06.065

Vanalle, R.M., Ganga, G.M.D., Godinho Filho, M., Lucato, W.C., 2017. Green supply chain management: An investigation of pressures, practices, and performance within the Brazilian automotive supply chain. J. Clean. Prod. 151, 250-259. doi:10.1016/j.jclepro.2017.03.066

Verstrepen, S., Cruijssen, F., Brito, M.P. De, Dullaert, W., 2007. An Exploratory Analysis of Reverse Logistics in Flanders. Eur. J. Transp. Infrastruct. Res. 4, 301-316.

Walker, H., Di Sisto, L., McBain, D., 2008. Drivers and barriers to environmental supply chain management practices: Lessons from the public and private sectors. J. Purch. Supply Manag. 14, 69-85. doi:10.1016/j.pursup.2008.01.007

Walker, H., Jones, N., 2012. Sustainable supply chain management across the UK private sector. Supply Chain Manag. An Int. J. 17, 15-28. doi:10.1108/13598541211212177

Wang, W.C., Lin, Y.H., Lin, C.L., Chung, C.H., Lee, M.T., 2012. DEMATEL-based model to improve the performance in a matrix organization. Expert Syst. Appl. 39, 4978-4986. doi:10.1016/j.eswa.2011.10.016

Wang, Z., Mathiyazhagan, K., Xu, L., Diabat, A., 2015. A decision making trial and evaluation laboratory approach to analyze the barriers to Green Supply Chain Management adoption in a food packaging company. J. Clean. Prod. doi:10.1016/j.jclepro.2015.09.142

Wang, Z., Subramanian, N., Gunasekaran, A., Abdulrahman, M.D., Liu, C., 2015. Composite sustainable manufacturing practice and performance framework: Chinese auto-parts suppliers' perspective. Int. J. Prod. Econ. 170, 219-233. doi:10.1016/j.ijpe.2015.09.035

Wu, H.H., Tsai, Y.N., 2011. A DEMATEL method to evaluate the causal relations among the criteria in auto spare parts industry. Appl. Math. Comput. 218, 2334-2342. doi:10.1016/j.amc.2011.07.055

Wüstenhagen, R., Bilharz, M., 2006. Green energy market development in Germany: effective public policy and emerging customer demand. Energy Policy 34, 1681-1696. doi:10.1016/j.enpol.2004.07.013

Xia, X., Govindan, K., Zhu, Q., 2015. Analyzing internal barriers for automotive parts remanufacturers in China using grey-DEMATEL approach. J. Clean. Prod. 87, 811-825. doi:10.1016/j.jclepro.2014.09.044

Yuan, C., Zhai, Q., Dornfeld, D., 2012. A three dimensional system approach for environmentally sustainable manufacturing. CIRP Ann. - Manuf. Technol. 61, 39-42. doi:10.1016/j.cirp.2012.03.105

Zaabi, S., Dhaheri, N., Diabat, A., 2013. Analysis of interaction between the barriers for the implementation of sustainable supply chain management. Int. J. Adv. Manuf. Technol. 68, 895-905. doi:10.1007/s00170-013-4951-8

Zailani, S., Jeyaraman, K., Vengadasan, G., Premkumar, R., 2012. Sustainable supply chain management (SSCM) in Malaysia: A survey. Int. J. Prod. Econ. doi:10.1016/j.ijpe.2012.02.008 
Zhu, Q., Sarkis, J., 2007. The moderating effects of institutional pressures on emergent green supply chain practices and performance. Int. J. Prod. Res. 45, 4333-4355. doi:10.1080/00207540701440345

Zhu, Q., Sarkis, J., 2006. An inter-sectoral comparison of green supply chain management in China: Drivers and practices. J. Clean. Prod. 14, 472-486. doi:10.1016/j.jclepro.2005.01.003

Zhu, Q., Sarkis, J., Lai, K., 2007. Green supply chain management: pressures, practices and performance within the Chinese automobile industry. J. Clean. Prod. 15, 1041-1052. doi:10.1016/j.jclepro.2006.05.021 


\section{List of Tables}

Table 1: Summary of literature that has used a grey DEMATEL approach

\begin{tabular}{|c|c|c|}
\hline Authors & Nature of the work & Application \\
\hline (Bouzon et al., 2017) & $\begin{array}{l}\text { Analysis of barriers to reverse logistics } \\
\text { implementation under a multiple } \\
\text { stakeholder perspective. }\end{array}$ & $\begin{array}{l}\text { Multiple stakeholders' } \\
\text { perspectives in a } \\
\text { Brazilian context. }\end{array}$ \\
\hline (Luthra et al., 2017) & $\begin{array}{l}\text { Analysis of drivers of the adoption of } \\
\text { sustainable consumption and production } \\
\text { practices. }\end{array}$ & $\begin{array}{l}\text { Automotive company, } \\
\text { Indian context. }\end{array}$ \\
\hline (Rajesh and Ravi, 2017) & $\begin{array}{l}\text { Analyzing drivers of risk in an } \\
\text { electronic supply chain. }\end{array}$ & $\begin{array}{l}\text { Indian electronic } \\
\text { company. }\end{array}$ \\
\hline (Shao et al., 2016) & $\begin{array}{l}\text { Evaluation of barriers between } \\
\text { environmentally-friendly products and } \\
\text { consumers. }\end{array}$ & $\begin{array}{l}\text { European automobile } \\
\text { industry. }\end{array}$ \\
\hline (Liang et al., 2016) & $\begin{array}{l}\text { Identification and analysis of critical } \\
\text { success factors for sustainable } \\
\text { development. }\end{array}$ & $\begin{array}{l}\text { Chinese biofuel } \\
\text { industry }\end{array}$ \\
\hline (Govindan et al., 2016) & $\begin{array}{l}\text { Application to select third party logistics } \\
\text { providers. }\end{array}$ & $\begin{array}{l}\text { Iranian } \\
\text { automotive } \\
\text { industry }\end{array}$ \\
\hline (Xia et al., 2015) & $\begin{array}{l}\text { Examining internal barriers to a } \\
\text { remanufacturing industry. }\end{array}$ & $\begin{array}{l}\text { Automotive parts } \\
\text { remanufacturer industry } \\
\text { in China. }\end{array}$ \\
\hline (Su et al., 2015) & $\begin{array}{l}\text { Evaluating sustainable supply chain } \\
\text { management performance. }\end{array}$ & $\begin{array}{l}\text { Taiwanese electronic } \\
\text { manufacturing focal } \\
\text { firm. }\end{array}$ \\
\hline (Rajesh and Ravi, 2015) & $\begin{array}{l}\text { Modeling enablers of supply chain } \\
\text { risk mitigation. }\end{array}$ & $\begin{array}{l}\text { Indian electronics } \\
\text { manufacturing } \\
\text { company. }\end{array}$ \\
\hline $\begin{array}{c}\text { (Özdemır and Tüysüz, } \\
\text { 2015) }\end{array}$ & Analyzing strategies of universities. & Turkish Universities. \\
\hline
\end{tabular}


Table 2: Research on SSCM and green practices

\begin{tabular}{|l|l|l|}
\hline \multicolumn{1}{|c|}{ Authors } & Nature of the contribution & \multicolumn{1}{|c|}{$\begin{array}{c}\text { Nature of the model/ } \\
\text { methodology }\end{array}$} \\
\hline (Gosling et al., 2017) & $\begin{array}{l}\text { The role of supply chain } \\
\text { leadership in the learning of } \\
\text { sustainable practice }\end{array}$ & Integrated conceptual model \\
\hline (Marcon et al., 2017) & $\begin{array}{l}\text { Innovation and } \\
\text { environmentally sustainable } \\
\text { economy }\end{array}$ & Exploratory research model \\
\hline $\begin{array}{l}\text { (de Camargo Fiorini and } \\
\text { Jabbour, 2017) }\end{array}$ & $\begin{array}{l}\text { Impact of information system } \\
\text { and sustainable supply chain } \\
\text { towards sustainable society }\end{array}$ & A structured literature review \\
\hline (Ahmadi et al., 2017) & $\begin{array}{l}\text { Social sustainability } \\
\text { assessment in supply chain }\end{array}$ & Best-worst method \\
\hline (Kusi-Sarpong et al., 2016) & $\begin{array}{l}\text { Green supply chain practice } \\
\text { assessment in the Ghanaian } \\
\text { mining industry }\end{array}$ & $\begin{array}{l}\text { Fuzzy-DEMATEL and } \\
\text { analytical network process } \\
\text { (ANP) }\end{array}$ \\
\hline (Bai et al., 2017) & $\begin{array}{l}\text { Evaluating the implementation } \\
\text { path for green information } \\
\text { technology systems in the } \\
\text { Ghanaian mining industry }\end{array}$ & $\begin{array}{l}\text { Grey numbers with } \\
\text { DEMATEL and the NK } \\
\text { fitness landscapes model (NK } \\
\text { model) }\end{array}$ \\
\hline (Mathivathanan et al., 2017) & $\begin{array}{l}\text { Evaluating SSCM practices in } \\
\text { Indian automotive industry }\end{array}$ & DEMATEL \\
\hline (Shi et al., 2017) & $\begin{array}{l}\text { Measuring corporate } \\
\text { sustainable development }\end{array}$ & $\begin{array}{l}\text { Interdependent closed-loop } \\
\text { hierarchical structure }\end{array}$ \\
\hline (Mani et al., 2016) & $\begin{array}{l}\text { Assessment of social } \\
\text { sustainability in Indian } \\
\text { manufacturing company }\end{array}$ & Semi-structured interview \\
\hline (Egilmez et al., 2014) & $\begin{array}{l}\text { Supply chain sustainability } \\
\text { assessment in the US food } \\
\text { processing sector. }\end{array}$ & $\begin{array}{l}\text { The Economic Input-Output } \\
\text { Life Cycle Assessment (EIO- } \\
\text { LCA) and data envelopment } \\
\text { analysis }\end{array}$ \\
\hline
\end{tabular}

Table 3: Value of Bangladesh's exported leather and leather products (million US\$)

\begin{tabular}{|l|l|l|l|l|}
\hline Category & $2011-12$ & $2012-13$ & $2013-14$ & $2014-15$ \\
\hline Leather & 330.16 & 399.73 & 505.54 & 397.54 \\
\hline Leather products & 99.36 & 161.62 & 240.09 & 249.16 \\
\hline Footwear & 335.51 & 419.32 & 378.54 & 483.81 \\
\hline Total & 765.03 & 980.67 & 1124.17 & 1130.51 \\
\hline Growth in Year & $17.51 \%$ & $28.19 \%$ & $32.12 \%$ & $.56 \%$ \\
\hline
\end{tabular}

Source: Bangladesh Export Promotion Bureau 
Table 4: Identification of major barriers to the adoption of sustainable supply chain management

\begin{tabular}{|c|c|c|}
\hline Barrier & Description & Relevant literature \\
\hline 1. Information gap & $\begin{array}{l}\text { Lack of knowledge about sustainability } \\
\text { and environmentally relevant issues. } \\
\text { Unwilling to implement green supply } \\
\text { chain in manufacturing system. }\end{array}$ & $\begin{array}{l}\text { Barve and Muduli } \\
\text { (2013), Muduli et al. } \\
\text { (2013). }\end{array}$ \\
\hline $\begin{array}{l}\text { 2. Costs of sustainability } \\
\text { and poor economic } \\
\text { conditions }\end{array}$ & $\begin{array}{l}\text { Lack of interest in investing money for } \\
\text { sustainability, and economic conditions } \\
\text { not as good as developed countries. }\end{array}$ & $\begin{array}{l}\text { Nidumolu et at. (2009), } \\
\text { Wang et al. (2015). }\end{array}$ \\
\hline $\begin{array}{l}\text { 3. Absence of society } \\
\text { pressure }\end{array}$ & $\begin{array}{l}\text { Pressure from community, NGOs and } \\
\text { environmental authorities is low. }\end{array}$ & $\begin{array}{l}\text { Zhigang Wang et al. } \\
\text { (2015), Govindan et al. } \\
\text { (2014). }\end{array}$ \\
\hline $\begin{array}{l}\text { 4. Lack of support and } \\
\text { guidelines from } \\
\text { regulatory } \\
\text { authority/poor } \\
\text { legislation }\end{array}$ & $\begin{array}{l}\text { Absence of strong environmental } \\
\text { legislation. }\end{array}$ & Nidumolu et al. (2009). \\
\hline $\begin{array}{l}\text { 5. Non-adoption of } \\
\text { cleaner technology }\end{array}$ & $\begin{array}{l}\text { Unwilling to adopt pollution control \& } \\
\text { prevention technology. }\end{array}$ & $\begin{array}{l}\text { Vachon and Klassen } \\
\text { (2007), Nowosielski } \\
\text { (2007). }\end{array}$ \\
\hline $\begin{array}{l}\text { 6. Lack of eco-literacy } \\
\text { amongst supply chain } \\
\text { partners }\end{array}$ & $\begin{array}{l}\text { Supply chain partner have insufficient } \\
\text { knowledge of sustainable manufacturing } \\
\text { practices. }\end{array}$ & $\begin{array}{l}\text { Li (2014), Tseng et al. } \\
\text { (2013). }\end{array}$ \\
\hline $\begin{array}{l}\text { Less practice on } \\
\text { reverse logistics }\end{array}$ & $\begin{array}{l}\text { Absence of reverse logistics facility. } \\
\text { Reverse logistics means the reuse or } \\
\text { recycling of returned products for } \\
\text { economic benefit. }\end{array}$ & $\begin{array}{l}\text { Jack et al. (2010), } \\
\text { Sarkis et al. (2010). }\end{array}$ \\
\hline 8. Capacity constraints & $\begin{array}{l}\text { Less facility and capacity for sustainable } \\
\text { manufacturing practices. }\end{array}$ & $\begin{array}{l}\text { Mudgal et al. (2010), } \\
\text { Muduli et al. (2013). }\end{array}$ \\
\hline $\begin{array}{l}\text { 9. Lack of commitment } \\
\text { from top management }\end{array}$ & $\begin{array}{l}\text { Sustainable manufacturing practice in } \\
\text { industry is ignored by top management. }\end{array}$ & $\begin{array}{l}\text { Turker and Altuntas } \\
\text { (2014). }\end{array}$ \\
\hline $\begin{array}{l}\text { 10. Inadequate supply } \\
\text { chain strategic } \\
\text { planning }\end{array}$ & $\begin{array}{l}\text { In leather processing factories, strong } \\
\text { supply chain strategic planning does not } \\
\text { exist. }\end{array}$ & $\begin{array}{l}\text { Baumgartner and } \\
\text { Korhonen (2010). }\end{array}$ \\
\hline $\begin{array}{l}\text { 11. Lack of market } \\
\text { demand }\end{array}$ & $\begin{array}{l}\text { People are not conscious about green } \\
\text { products, resulting in a lack of demand. }\end{array}$ & Lin et al. (2013). \\
\hline $\begin{array}{l}\text { 12. Pressure for lower } \\
\text { prices }\end{array}$ & $\begin{array}{l}\text { In today's competitive market green } \\
\text { products have higher prices and are } \\
\text { therefore in less demand. }\end{array}$ & $\begin{array}{l}\text { Khidir and Zailani } \\
\text { (2009), Koho et al. } \\
\text { (2011). }\end{array}$ \\
\hline $\begin{array}{l}\text { 13. Lack of training and } \\
\text { education on } \\
\text { sustainability }\end{array}$ & $\begin{array}{l}\text { Lack of knowledge about sustainable } \\
\text { manufacturing practices. Insufficient } \\
\text { programs arranged by environmental } \\
\text { authorities. }\end{array}$ & $\begin{array}{l}\text { Dubey and } \\
\text { Gunasekaran (2015), } \\
\text { Jabbour (2013a). }\end{array}$ \\
\hline
\end{tabular}




\begin{tabular}{|c|c|c|}
\hline $\begin{array}{l}\text { 14. Lack of environmental } \\
\text { requirements }\end{array}$ & $\begin{array}{l}\text { Environmental management system } \\
\text { incorporates operations and manages the } \\
\text { entire environmental requirement. }\end{array}$ & $\begin{array}{l}\text { Le Bourhis et al. } \\
\text { (2013), Yuan et al. } \\
\text { (2012). }\end{array}$ \\
\hline $\begin{array}{l}\text { 15. Lack of sustainable } \\
\text { communication } \\
\text { technology }\end{array}$ & $\begin{array}{l}\text { Inadequate application of e-ordering, } \\
\text { companywide enterprise resource planning } \\
\text { (ERP) and intelligent network system. }\end{array}$ & Sandhu et al. (2012). \\
\hline $\begin{array}{l}\text { 16. Restrictive company } \\
\text { policies towards } \\
\text { product/process } \\
\text { stewardship }\end{array}$ & $\begin{array}{l}\text { Less control over minimizing } \\
\text { environmental impact during the design, } \\
\text { production or sale of products over their } \\
\text { entire life cycle. }\end{array}$ & Mudgal (2010) \\
\hline $\begin{array}{l}\text { 17. Lack interest in sharing } \\
\text { risks and rewards }\end{array}$ & $\begin{array}{l}\text { Industries are not interested in sharing } \\
\text { risks and rewards for adopting } \\
\text { environmentally-friendly concepts. }\end{array}$ & (Shao et al., 2016) \\
\hline $\begin{array}{l}\text { 18. Organizational } \\
\text { boundaries }\end{array}$ & $\begin{array}{l}\text { Lack of skilled staff, lack of experience, } \\
\text { low financial resources or capital access, } \\
\text { green issues have low priority in the } \\
\text { leather industries of Bangladesh. }\end{array}$ & $\begin{array}{l}\text { Lee et al. (2012), } \\
\text { Sarkis (2012), Sarkis et } \\
\text { al. (2011). }\end{array}$ \\
\hline $\begin{array}{l}\text { 19. Poor supplier } \\
\text { commitment }\end{array}$ & $\begin{array}{l}\text { Lack of commitment between suppliers } \\
\text { and customers. In leather industries, } \\
\text { companies are often unwilling to exchange } \\
\text { information. }\end{array}$ & $\begin{array}{l}\text { Vachon and Klassen } \\
\text { (2006), Hong et al. } \\
(2009) \text {. }\end{array}$ \\
\hline $\begin{array}{l}\text { 20. Lack of awareness of } \\
\text { local customers in } \\
\text { green product }\end{array}$ & $\begin{array}{l}\text { Local customers are not aware of green } \\
\text { products. }\end{array}$ & $\begin{array}{l}\text { Bhanot et al. (2015), } \\
\text { Raci and Shankar } \\
(2005) .\end{array}$ \\
\hline $\begin{array}{l}\text { 21. Unskilled human } \\
\text { resources }\end{array}$ & $\begin{array}{l}\text { Lack of quality worker and management } \\
\text { personnel to implement sustainable } \\
\text { manufacturing practice. }\end{array}$ & $\begin{array}{l}\text { Parker et al. (2009), } \\
\text { Hillary (2004), Nejati et } \\
\text { al., (2017) }\end{array}$ \\
\hline $\begin{array}{l}\text { 22. Lack of technical } \\
\text { expertise }\end{array}$ & $\begin{array}{l}\text { Inadequate knowledge to design a } \\
\text { pollution-free product to implement } \\
\text { sustainable manufacturing practice. }\end{array}$ & $\begin{array}{l}\text { Revell and Rutherfoord } \\
\text { (2003). }\end{array}$ \\
\hline $\begin{array}{l}\text { 23. Lack of government } \\
\text { support to adopt } \\
\text { sustainable } \\
\text { manufacturing } \\
\text { practice. }\end{array}$ & $\begin{array}{l}\text { Government regulations are not enough to } \\
\text { adopt sustainable manufacturing practice. }\end{array}$ & $\begin{array}{l}\text { Prakash and Barua } \\
(2015), \text { Govindan et al. } \\
(2013) .\end{array}$ \\
\hline $\begin{array}{l}\text { 24. Misalignment of short- } \\
\text { and long-term strategic } \\
\text { goals }\end{array}$ & $\begin{array}{l}\text { Lack of consciousness to align short- and } \\
\text { long-term strategies. }\end{array}$ & $\begin{array}{l}\text { Cowan (2008), Walker } \\
\text { and Jones (2012). }\end{array}$ \\
\hline 25. Uncertain benefits & $\begin{array}{l}\text { Insignificant economic advantage, } \\
\text { slow return on investment. }\end{array}$ & Mittal et al. (2013). \\
\hline $\begin{array}{l}\text { 26. Resistance to change } \\
\text { and adopting } \\
\text { innovation }\end{array}$ & Less interest in adopting innovation. & $\begin{array}{l}\text { Gaziulusoy et al. } \\
\text { (2013). }\end{array}$ \\
\hline 27. Power shortages & Lack power supply during blackouts. & Bhanot et al. (2015) \\
\hline
\end{tabular}




\begin{tabular}{|l|l|l|}
\hline $\begin{array}{l}\text { 28. Lack of funds for } \\
\text { sustainable } \\
\text { manufacturing practice }\end{array}$ & $\begin{array}{l}\text { Bank and other financial institute offer } \\
\text { fewer funds for green projects. }\end{array}$ & $\begin{array}{l}\text { Kulatunga et al. } \\
\text { (2013). }\end{array}$ \\
\hline $\begin{array}{l}\text { 29. Low availability of } \\
\text { credit }\end{array}$ & $\begin{array}{l}\text { Less ability to get funds from bank and } \\
\text { financial institute with low interest rate. }\end{array}$ & $\begin{array}{l}\text { Bhanot et al. (2015), } \\
\text { Kulatunga et al. } \\
\text { (2013), Wang et al. } \\
\text { (2015). }\end{array}$ \\
\hline $\begin{array}{l}\text { 30. Lack of training } \\
\text { courses and institutions } \\
\text { to train specific } \\
\text { personnel. }\end{array}$ & $\begin{array}{l}\text { Lack of ability to train people for } \\
\text { sustainable development in leather sector. }\end{array}$ & Govindan et al. (2014) \\
\hline $\begin{array}{l}\text { 31. Less business-friendly } \\
\text { policies }\end{array}$ & Absence of business-friendly policies & This study \\
\hline $\begin{array}{l}\text { 32. Limited access to } \\
\text { market information }\end{array}$ & $\begin{array}{l}\text { The facility to access global market } \\
\text { information is less. }\end{array}$ & (Technical Report, \\
\hline $\begin{array}{l}\text { 33. Higher prices of } \\
\text { imported processing } \\
\text { chemicals for } \\
\text { hides/skins }\end{array}$ & Price of imported chemicals is very high. & (Technical Report, \\
\hline $\begin{array}{l}\text { 34. Outdated machinery in } \\
\text { tanneries }\end{array}$ & $\begin{array}{l}\text { Outdated machineries present in tannery } \\
\text { industry. }\end{array}$ & This study \\
\hline $\begin{array}{l}\text { 35. Absence of integrated } \\
\text { policies }\end{array}$ & $\begin{array}{l}\text { Policy maker does not consider integration } \\
\text { of policies. }\end{array}$ & (Technical Report, \\
2013). \\
\hline
\end{tabular}


Table 5: Selection of common barriers with the help of experts and academic feedback

\begin{tabular}{|c|c|c|}
\hline Barrier Category & Barrier & $\begin{array}{l}\text { Identification } \\
\text { Code }\end{array}$ \\
\hline \multirow{4}{*}{ A. Environment } & Lack of eco-literacy amongst supply chain partner & (E1) \\
\hline & Lack of environmental requirement & (E2) \\
\hline & Lack of practice on reverse logistics & (E3) \\
\hline & $\begin{array}{l}\text { Lack of awareness of local customers in green } \\
\text { product }\end{array}$ & (E4) \\
\hline \multirow[t]{4}{*}{ B. Technology } & Lack of technical expertise & (T1) \\
\hline & Resistance to change and adopt innovation & (T2) \\
\hline & Lack of cleaner technology & (T3) \\
\hline & Outdated machineries & (T4) \\
\hline \multirow{4}{*}{$\begin{array}{l}\text { C. Knowledge \& } \\
\text { Support }\end{array}$} & Information gap & (KS1) \\
\hline & Lack of commitment from top management & (KS2) \\
\hline & Lack of training and education about sustainability & (KS3) \\
\hline & Limited access to market information & (KS4) \\
\hline \multirow[t]{4}{*}{ D. Society } & $\begin{array}{l}\text { Lack of government support \& guideline to adopt } \\
\text { sustainable supply chain practices }\end{array}$ & (S1) \\
\hline & Absence of society pressure & $(\mathrm{S} 2)$ \\
\hline & Lack demand \& pressure for lower price & (S3) \\
\hline & Less of business friendly policy & (S4) \\
\hline \multirow[t]{4}{*}{ E. Financial } & Cost of sustainability \& economic condition & (F1) \\
\hline & Capacity constraints & (F2) \\
\hline & Lack of funds for sustainable supply chain practices & (F3) \\
\hline & Green power shortage & (F4) \\
\hline
\end{tabular}


Table 6: Average grey relation matrix for barriers to SSCM implementation

\begin{tabular}{|c|c|c|c|c|c|c|c|c|c|c|c|c|c|c|c|c|c|c|c|c|}
\hline & E1 & E2 & $\mathbf{E 3}$ & E4 & T1 & T2 & T3 & T4 & KS1 & KS2 & KS3 & KS4 & S1 & S2 & S3 & S4 & F1 & F2 & F3 & F4 \\
\hline \multirow[t]{2}{*}{ E1 } & 0 & 0.6 & 0.2 & 0.15 & 0.6 & 0.2 & 0.9 & 0.4 & 0.675 & 0.5 & 0.4 & 0.2 & 0.5 & 0.55 & 0.2 & 0.1 & 0.4 & 0.2 & 0.2 & 0.1 \\
\hline & 0.1 & 0.9 & 0.5 & 0.4 & 0.9 & 0.5 & 1 & 0.7 & 0.925 & 0.8 & 0.7 & 0.5 & 0.8 & 0.85 & 0.5 & 0.3 & 0.7 & 0.5 & 0.5 & 0.3 \\
\hline \multirow{2}{*}{ E2 } & 0.4 & 0 & 0.6 & 0.1 & 0.1 & 0.4 & 0.2 & 0.2 & 0.2 & 0.2 & 0.125 & 0.2 & 0.4 & 0.2 & 0.1 & 0.1 & 0.2 & 0.6 & 0.1 & 0.1 \\
\hline & 0.7 & 0.1 & 0.9 & 0.3 & 0.3 & 0.7 & 0.5 & 0.5 & 0.5 & 0.5 & 0.35 & 0.5 & 0.7 & 0.5 & 0.3 & 0.3 & 0.5 & 0.9 & 0.3 & 0.3 \\
\hline \multirow[t]{2}{*}{$\mathbf{E 3}$} & 0.2 & 0.1 & 0 & 0.2 & 0.2 & 0.475 & 0.4 & 0.6 & 0.4 & 0.4 & 0.2 & 0.2 & 0.2 & 0.2 & 0.1 & 0.1 & 0.2 & 0.6 & 0.1 & 0.1 \\
\hline & 0.5 & 0.3 & 0.1 & 0.5 & 0.5 & 0.75 & 0.7 & 0.9 & 0.7 & 0.7 & 0.5 & 0.5 & 0.5 & 0.5 & 0.3 & 0.3 & 0.5 & 0.9 & 0.3 & 0.3 \\
\hline \multirow[t]{2}{*}{ E4 } & 0.6 & 0.4 & 0.5 & 0 & 0.6 & 0.4 & 0.45 & 0.4 & 0.6 & 0.825 & 0.125 & 0.4 & 0.45 & 0.6 & 0.2 & 0.2 & 0.6 & 0.4 & 0.2 & 0.2 \\
\hline & 0.9 & 0.7 & 0.8 & 0.1 & 0.9 & 0.7 & 0.75 & 0.7 & 0.9 & 0.975 & 0.35 & 0.7 & 0.75 & 0.9 & 0.5 & 0.5 & 0.9 & 0.7 & 0.5 & 0.5 \\
\hline \multirow[t]{2}{*}{ T1 } & 0.6 & 0.1 & 0.2 & 0.4 & 0 & 0.2 & 0.2 & 0.2 & 0.4 & 0.4 & 0.4 & 0.1 & 0.4 & 0.6 & 0.2 & 0.1 & 0.4 & 0.2 & 0.2 & 0.1 \\
\hline & 0.9 & 0.3 & 0.5 & 0.7 & 0.1 & 0.5 & 0.5 & 0.5 & 0.7 & 0.7 & 0.7 & 0.3 & 0.7 & 0.9 & 0.5 & 0.3 & 0.7 & 0.5 & 0.5 & 0.3 \\
\hline \multirow[t]{2}{*}{$\mathbf{T} 2$} & 0.2 & 0.1 & 0.55 & 0.2 & 0.2 & 0 & 0.2 & 0.6 & 0.4 & 0.2 & 0.2 & 0.4 & 0.2 & 0.4 & 0.1 & 0.1 & 0.2 & 0.4 & 0.1 & 0.1 \\
\hline & 0.5 & 0.3 & 0.85 & 0.5 & 0.5 & 0.1 & 0.5 & 0.9 & 0.7 & 0.5 & 0.5 & 0.7 & 0.5 & 0.7 & 0.3 & 0.3 & 0.5 & 0.7 & 0.3 & 0.3 \\
\hline \multirow[t]{2}{*}{ T3 } & 0.25 & 0.2 & 0.3 & 0.6 & 0.55 & 0.6 & 0 & 0.25 & 0.55 & 0.45 & 0.4 & 0.4 & 0.4 & 0.35 & 0.2 & 0.1 & 0.6 & 0.4 & 0.6 & 0.2 \\
\hline & 0.55 & 0.5 & 0.6 & 0.9 & 0.85 & 0.9 & 0.1 & 0.55 & 0.85 & 0.75 & 0.7 & 0.7 & 0.7 & 0.65 & 0.5 & 0.3 & 0.9 & 0.7 & 0.9 & 0.5 \\
\hline \multirow[t]{2}{*}{ T4 } & 0.4 & 0.2 & 0.2 & 0.2 & 0.2 & 0.2 & 0.6 & 0 & 0.4 & $\begin{array}{ll}0.4 \\
\end{array}$ & 0.2 & 0.6 & 0.2 & 0.4 & 0.6 & 0.1 & 0.2 & 0.6 & 0.1 & 0.1 \\
\hline & 0.7 & 0.5 & 0.5 & 0.5 & 0.5 & 0.5 & 0.9 & 0.1 & 0.7 & 0.7 & 0.5 & 0.9 & 0.5 & 0.7 & 0.9 & 0.3 & 0.5 & 0.9 & 0.3 & 0.3 \\
\hline \multirow[t]{2}{*}{ KS1 } & 0.45 & 0.4 & 0.35 & 0.45 & 0.6 & 0.35 & 0.45 & 0.45 & 0 & 0.6 & 0.125 & 0.45 & 0.6 & 0.55 & 0.4 & 0.2 & 0.6 & 0.4 & 0.6 & 0.6 \\
\hline & 0.75 & 0.7 & 0.65 & 0.75 & 0.9 & 0.65 & 0.75 & 0.75 & 0.1 & 0.9 & 0.35 & 0.75 & 0.9 & 0.85 & 0.7 & 0.5 & 0.9 & 0.7 & 0.9 & 0.9 \\
\hline \multirow[t]{2}{*}{ KS2 } & 0.6 & 0.4 & 0.55 & 0.6 & 0.4 & 0.35 & 0.6 & 0.6 & 0.6 & 0 & 0.15 & 0.6 & 0.55 & 0.825 & 0.2 & 0.55 & 0.6 & 0.4 & 0.25 & 0.4 \\
\hline & 0.9 & 0.7 & 0.85 & 0.9 & 0.7 & 0.65 & 0.9 & 0.9 & 0.9 & 0.1 & 0.4 & 0.9 & 0.7 & 0.975 & 0.5 & 0.85 & 0.9 & 0.7 & 0.55 & 0.7 \\
\hline \multirow[t]{2}{*}{ KS3 } & 0.1 & 0.2 & 0.1 & 0.1 & 0.1 & $\begin{array}{ll}0.1 \\
\end{array}$ & 0.2 & 0.4 & 0.35 & 0.2 & 0 & 0.2 & 0.2 & 0.4 & 0.075 & 0.4 & 0.2 & 0.1 & 0.55 & 0.2 \\
\hline & 0.3 & 0.5 & 0.3 & 0.3 & 0.3 & 0.3 & 0.5 & $\begin{array}{l}0.7 \\
\end{array}$ & 0.65 & 0.5 & 0.1 & 0.5 & 0.5 & 0.7 & 0.25 & 0.7 & 0.5 & 0.3 & 0.85 & 0.5 \\
\hline \multirow[t]{2}{*}{ KS4 } & 0.6 & 0.25 & 0.2 & 0.4 & 0.6 & 0.2 & 0.6 & 0.6 & 0.6 & 0.45 & 0.1 & 0 & 0.4 & 0.6 & 0.6 & 0.125 & 0.6 & 0.2 & 0.2 & 0.125 \\
\hline & 0.9 & 0.55 & 0.5 & 0.7 & 0.9 & 0.5 & 0.9 & 0.9 & 0.9 & 0.75 & 0.3 & 0.1 & 0.7 & 0.9 & 0.9 & 0.35 & 0.9 & 0.5 & 0.5 & 0.35 \\
\hline \multirow[t]{2}{*}{ S1 } & 0.15 & 0.6 & 0.6 & 0.2 & 0.6 & 0.2 & 0.6 & 0.4 & 0.55 & 0.55 & 0.5 & 0.2 & 0 & 0.4 & 0.55 & 0.6 & 0.45 & 0.55 & 0.6 & 0.6 \\
\hline & 0.4 & 0.9 & 0.9 & 0.5 & 0.9 & 0.5 & 0.9 & 0.7 & 0.85 & 0.85 & 0.8 & 0.5 & 0.1 & 0.7 & 0.85 & 0.9 & 0.75 & 0.85 & 0.9 & 0.9 \\
\hline \multirow[t]{2}{*}{ S2 } & 0.4 & 0.4 & 0.35 & 0.4 & 0.4 & 0.2 & 0.6 & 0.4 & 0.75 & 0.675 & 0.25 & 0.4 & 0.6 & 0 & 0.2 & 0.5 & 0.6 & 0.4 & 0.2 & 0.125 \\
\hline & 0.7 & 0.7 & 0.65 & 0.7 & 0.7 & 0.5 & 0.9 & 0.7 & 0.95 & 0.925 & 0.55 & 0.7 & 0.9 & 0.1 & 0.5 & 0.8 & 0.9 & 0.7 & 0.5 & 0.35 \\
\hline \multirow[t]{2}{*}{$\mathbf{S 3}$} & 0.1 & 0.2 & 0.125 & 0.2 & 0.2 & 0.1 & 0.2 & 0.125 & 0.2 & 0.4 & 0.2 & 0.6 & 0.2 & 0.1 & 0 & 0.1 & 0.2 & 0.6 & 0.4 & 0.1 \\
\hline & 0.3 & 0.5 & 0.35 & 0.5 & 0.5 & 0.3 & 0.5 & 0.35 & 0.5 & 0.7 & 0.5 & 0.9 & 0.5 & 0.3 & 0.1 & 0.3 & 0.5 & 0.9 & 0.7 & 0.3 \\
\hline \multirow[t]{2}{*}{ S4 } & 0.1 & 0.2 & 0.2 & 0.2 & 0.1 & 0.2 & 0.2 & 0.4 & $\begin{array}{l}0.1 \\
\end{array}$ & 0.2 & 0.2 & 0.4 & 0.2 & 0.2 & 0.1 & 0 & 0.2 & 0.1 & 0.2 & 0.2 \\
\hline & 0.3 & 0.5 & 0.5 & 0.5 & 0.3 & 0.5 & 0.5 & 0.7 & 0.3 & 0.5 & 0.5 & 0.7 & 0.5 & 0.5 & 0.3 & 0.1 & 0.5 & 0.3 & 0.5 & 0.7 \\
\hline \multirow[t]{2}{*}{ F1 } & 0.55 & 0.4 & 0.45 & 0.6 & 0.6 & 0.4 & 0.6 & 0.45 & 0.9 & 0.6 & 0.175 & 0.575 & 0.6 & 0.25 & 0.2 & 0.1 & 0 & 0.6 & 0.2 & 0.6 \\
\hline & 0.85 & 0.7 & 0.75 & 0.9 & 0.9 & 0.7 & 0.9 & 0.75 & 1 & 0.9 & 0.45 & 0.825 & 0.9 & 0.55 & 0.5 & 0.3 & 0.1 & 0.9 & 0.5 & 0.9 \\
\hline \multirow[t]{2}{*}{ F2 } & 0.2 & 0.4 & 0.6 & 0.4 & 0.2 & 0.2 & 0.2 & 0.6 & 0.4 & 0.4 & 0.2 & 0.1 & 0.6 & 0.4 & 0.2 & 0.2 & 0.4 & 0 & 0.1 & 0.1 \\
\hline & 0.5 & 0.7 & 0.9 & 0.7 & 0.5 & 0.5 & 0.5 & 0.9 & 0.7 & 0.7 & 0.5 & 0.3 & 0.9 & 0.7 & 0.5 & 0.5 & 0.7 & 0.1 & 0.3 & 0.3 \\
\hline F3 & 0.1 & 0.2 & 0.125 & 0.2 & 0.2 & 0.1 & 0.1 & 0.1 & 0.2 & 0.1 & 0.4 & 0.6 & 0.6 & 0.2 & 0.4 & 0.4 & 0.2 & 0.1 & 0 & 0.4 \\
\hline & 0.3 & 0.5 & 0.35 & 0.5 & 0.5 & 0.3 & 0.3 & 0.3 & 0.5 & 0.3 & 0.7 & 0.9 & 0.9 & 0.5 & 0.7 & 0.7 & 0.5 & 0.3 & 0.1 & 0.7 \\
\hline F4 & 0.1 & 0.1 & 0.1 & 0.2 & 0.1 & 0.1 & 0.1 & 0.1 & 0.2 & 0.1 & 0.4 & 0.6 & 0.4 & 0.2 & 0.1 & 0.4 & 0.2 & 0.1 & 0.4 & 0 \\
\hline & 0.3 & 0.3 & 0.3 & 0.5 & 0.3 & 0.3 & 0.3 & 0.3 & 0.5 & $\begin{array}{l}0.3 \\
\end{array}$ & 0.7 & 0.9 & 0.7 & 0.5 & 0.3 & 0.7 & 0.5 & 0.3 & 0.7 & 0.1 \\
\hline
\end{tabular}

*E1 indicates the identification code of "Lack of eco-literacy amongst supply chain partners", which is shown in Table 5. Another barrier is also shown in Table 5 by identification code. The level of influence of SSCM practices barriers $i$ over $j$ is represented as the grey value $\left[\frac{\otimes y_{i j}}{\overline{\bar{\otimes}} y_{i j}}\right]$. 
Table 7: Total relation matrix for barriers to SCCM implementation

\begin{tabular}{|c|c|c|c|c|c|c|c|c|c|c|c|c|c|c|c|c|c|c|c|c|}
\hline & E1 & E2 & $\mathbf{E 3}$ & E4 & $\mathbf{T 1}$ & $\mathbf{T} 2$ & T3 & T4 & KS1 & KS2 & KS3 & KS4 & S1 & S2 & S3 & S4 & F1 & F2 & F3 & F4 \\
\hline E1 & 0.110 & 0.160 & 0.135 & 0.123 & 0.180 & 0.114 & 0.202 & 0.166 & 0.206 & 0.182 & 0.128 & 0.142 & 0.185 & 0.183 & 0.109 & 0.087 & 0.169 & 0.145 & 0.117 & 0.091 \\
\hline E2 & 0.121 & 0.069 & 0.146 & 0.084 & 0.093 & 0.110 & 0.115 & 0.117 & 0.124 & 0.117 & 0.074 & 0.107 & 0.138 & 0.113 & 0.071 & 0.064 & 0.113 & 0.152 & 0.073 & 0.066 \\
\hline $\mathbf{E 3}$ & 0.103 & 0.081 & 0.082 & 0.101 & 0.108 & 0.115 & 0.135 & 0.156 & 0.145 & 0.137 & 0.084 & 0.110 & 0.119 & 0.116 & 0.074 & 0.065 & 0.115 & 0.152 & 0.076 & 0.068 \\
\hline E4 & 0.192 & 0.157 & 0.183 & 0.123 & 0.201 & 0.149 & 0.196 & 0.190 & 0.227 & 0.225 & 0.111 & 0.181 & 0.202 & 0.209 & 0.123 & 0.111 & 0.210 & 0.184 & 0.128 & 0.116 \\
\hline $\mathbf{T 1}$ & 0.151 & 0.092 & 0.113 & 0.128 & 0.097 & 0.095 & 0.128 & 0.125 & 0.158 & 0.150 & 0.112 & 0.107 & 0.150 & 0.165 & 0.092 & 0.074 & 0.146 & 0.120 & 0.099 & 0.076 \\
\hline T2 & 0.102 & 0.079 & 0.136 & 0.098 & 0.107 & 0.064 & 0.115 & 0.154 & 0.143 & 0.117 & 0.082 & 0.127 & 0.116 & 0.133 & 0.073 & 0.064 & 0.113 & 0.130 & 0.074 & 0.066 \\
\hline T3 & 0.144 & 0.126 & 0.151 & 0.174 & 0.182 & 0.157 & 0.132 & 0.161 & 0.206 & 0.185 & 0.132 & 0.170 & 0.183 & 0.172 & 0.114 & 0.092 & 0.195 & 0.169 & 0.159 & 0.109 \\
\hline T4 & 0.137 & 0.108 & 0.118 & 0.115 & 0.126 & 0.101 & 0.171 & 0.108 & 0.164 & 0.156 & 0.095 & 0.165 & 0.137 & 0.151 & 0.138 & 0.075 & 0.133 & 0.167 & 0.090 & 0.077 \\
\hline KS1 & 0.179 & 0.160 & 0.171 & 0.174 & 0.203 & 0.145 & 0.198 & 0.196 & 0.169 & 0.217 & 0.116 & 0.193 & 0.222 & 0.207 & 0.147 & 0.116 & 0.213 & 0.187 & 0.172 & 0.159 \\
\hline KS2 & 0.201 & 0.167 & 0.198 & 0.195 & 0.193 & 0.153 & 0.223 & 0.221 & 0.240 & 0.166 & 0.123 & 0.214 & 0.216 & 0.232 & 0.132 & 0.153 & 0.222 & 0.196 & 0.143 & 0.144 \\
\hline KS3 & 0.073 & 0.080 & 0.074 & 0.072 & 0.078 & 0.062 & 0.096 & 0.115 & 0.118 & 0.098 & 0.050 & 0.097 & 0.102 & 0.115 & 0.060 & 0.090 & 0.097 & 0.080 & 0.113 & 0.072 \\
\hline KS4 & 0.183 & 0.135 & 0.143 & 0.158 & 0.193 & 0.121 & 0.201 & 0.196 & 0.215 & 0.191 & 0.102 & 0.130 & 0.186 & 0.199 & 0.157 & 0.094 & 0.200 & 0.156 & 0.123 & 0.100 \\
\hline S1 & 0.141 & 0.174 & 0.190 & 0.146 & 0.195 & 0.128 & 0.204 & 0.187 & 0.217 & 0.205 & 0.153 & 0.165 & 0.154 & 0.187 & 0.156 & 0.153 & 0.192 & 0.198 & 0.171 & 0.157 \\
\hline S2 & 0.167 & 0.154 & 0.164 & 0.162 & 0.177 & 0.126 & 0.205 & 0.184 & 0.227 & 0.213 & 0.123 & 0.177 & 0.210 & 0.142 & 0.120 & 0.138 & 0.205 & 0.179 & 0.127 & 0.106 \\
\hline S3 & 0.080 & 0.086 & 0.084 & 0.091 & 0.098 & 0.067 & 0.102 & 0.094 & 0.112 & 0.124 & 0.076 & 0.138 & 0.108 & 0.092 & 0.056 & 0.060 & 0.104 & 0.138 & 0.101 & 0.061 \\
\hline S4 & 0.071 & 0.076 & 0.084 & 0.081 & 0.074 & 0.073 & 0.093 & 0.112 & 0.088 & 0.094 & 0.070 & 0.111 & 0.095 & 0.092 & 0.059 & 0.042 & 0.092 & 0.077 & 0.074 & 0.077 \\
\hline F1 & 0.192 & 0.162 & 0.185 & 0.191 & 0.208 & 0.154 & 0.216 & 0.201 & 0.248 & 0.221 & 0.124 & 0.202 & 0.224 & 0.184 & 0.129 & 0.104 & 0.155 & 0.210 & 0.136 & 0.160 \\
\hline F2 & 0.117 & 0.128 & 0.160 & 0.132 & 0.124 & 0.102 & 0.134 & 0.171 & 0.163 & 0.156 & 0.095 & 0.113 & 0.174 & 0.150 & 0.098 & 0.089 & 0.150 & 0.108 & 0.088 & 0.080 \\
\hline F3 & 0.079 & 0.087 & 0.083 & 0.090 & 0.099 & 0.066 & 0.092 & 0.091 & 0.113 & 0.094 & 0.100 & 0.142 & 0.147 & 0.104 & 0.101 & 0.095 & 0.104 & 0.087 & 0.063 & 0.097 \\
\hline F4 & 0.070 & 0.065 & 0.070 & 0.081 & 0.076 & 0.059 & 0.081 & 0.080 & 0.100 & 0.082 & 0.092 & 0.131 & 0.116 & 0.093 & 0.060 & 0.088 & 0.093 & 0.075 & 0.096 & 0.047 \\
\hline
\end{tabular}

*E1 indicates the identification code of "Lack of eco-literacy amongst supply chain partner" which is shown in Table 5. Another barrier is also shown in Table $\mathbf{5}$ by identification code. Threshold value $($ mean + standard deviation $)=0.178$. 
Table 8: Cause-effect parameters for barriers to SCCM implementation

\begin{tabular}{|c|c|c|c|c|}
\hline Barrier & $\boldsymbol{R}_{\boldsymbol{i}}$ & $\boldsymbol{C}_{\boldsymbol{j}}$ & $\boldsymbol{R}_{\boldsymbol{i}}+\boldsymbol{C}_{\boldsymbol{j}}$ & $\boldsymbol{R}_{\boldsymbol{i}}-\boldsymbol{C}_{\boldsymbol{j}}$ \\
\hline $\mathbf{E 1}$ & 2.9344 & 2.6142 & 5.5486 & 0.3202 \\
\hline $\mathbf{E 2}$ & 2.0668 & 2.3437 & 4.4106 & -0.2769 \\
\hline $\mathbf{E 3}$ & 2.1422 & 2.6699 & 4.8121 & -0.5277 \\
\hline $\mathbf{E 4}$ & 3.4171 & 2.5175 & 5.9346 & 0.8996 \\
\hline T1 & 2.3769 & 2.8122 & 5.1892 & -0.4353 \\
\hline T2 & 2.0938 & 2.1596 & 4.2534 & -0.0657 \\
\hline T3 & 3.1116 & 3.0378 & 6.1494 & 0.0738 \\
\hline T4 & 2.5322 & 3.0257 & 5.5579 & -0.4935 \\
\hline KS1 & 3.5438 & 3.3831 & 6.9270 & 0.1607 \\
\hline KS2 & 3.7315 & 3.1302 & 6.8617 & 0.6012 \\
\hline KS3 & 1.7430 & 2.0431 & 3.7861 & -0.3001 \\
\hline KS4 & 3.1841 & 2.9222 & 6.1063 & 0.2618 \\
\hline S1 & 3.4718 & 3.1841 & 6.6559 & 0.2876 \\
\hline S2 & 3.3046 & 3.0390 & 6.3436 & 0.2656 \\
\hline S3 & 1.8730 & 2.0670 & 3.9400 & -0.1941 \\
\hline S4 & 1.6322 & 1.8545 & 3.4866 & -0.2223 \\
\hline F1 & 3.6071 & 3.0216 & 6.6287 & 0.5856 \\
\hline F2 & 2.5350 & 2.9101 & 5.4451 & -0.3750 \\
\hline F3 & 1.9331 & 2.2249 & 4.1580 & -0.2918 \\
\hline F4 & 1.6563 & 1.9300 & 3.5863 & -0.2737 \\
\hline
\end{tabular}


Table 9: Final evaluation of barriers with ranking

\begin{tabular}{|c|c|c|c|}
\hline Rank & $\begin{array}{l}\text { Barrier name and identification } \\
\text { code }\end{array}$ & Rank & Cause group \\
\hline 1 & Information gap (KS1) & 1 & $\begin{array}{l}\text { Lack of awareness of local customers in green } \\
\text { product (E4) }\end{array}$ \\
\hline 2 & $\begin{array}{l}\text { Lack of commitment from top } \\
\text { management (KS2) }\end{array}$ & 2 & Lack of commitment from top management (KS2) \\
\hline 3 & $\begin{array}{l}\text { Lack of support and guideline from } \\
\text { regulatory authority (S1) }\end{array}$ & 3 & Cost of sustainability \& economic condition (F1) \\
\hline 4 & $\begin{array}{l}\text { Cost of sustainability \& economic } \\
\text { condition (F1) }\end{array}$ & 4 & $\begin{array}{l}\text { Lack of eco-literacy amongst supply chain partner } \\
\text { (E1) }\end{array}$ \\
\hline 5 & Absence of society pressure (S2) & 5 & $\begin{array}{l}\text { Lack of support and guideline from regulatory } \\
\text { authority (S1) }\end{array}$ \\
\hline 6 & Lack of cleaner technology (T3) & 6 & Absence of society pressure (S2) \\
\hline 7 & $\begin{array}{l}\text { Lack of training and education about } \\
\text { sustainability (KS4) }\end{array}$ & 7 & $\begin{array}{l}\text { Lack of training and education about sustainability } \\
\text { (KS4) }\end{array}$ \\
\hline 8 & $\begin{array}{l}\text { Lack of awareness of local customers } \\
\text { in green product (E4) }\end{array}$ & 8 & Information gap (KS1) \\
\hline 9 & Outdated machineries (T4) & 9 & Lack of cleaner technology (T3) \\
\hline \multirow{2}{*}{10} & \multirow{2}{*}{$\begin{array}{l}\text { Lack of eco-literacy amongst supply } \\
\text { chain partner (E1) }\end{array}$} & Rank & Effect Group \\
\hline & & 1 & Resistance to change and adopt innovation (T2) \\
\hline 11 & Capacity constraints (F2) & 2 & Lack demand \& pressure for lower price (S3) \\
\hline 12 & Lack of technical expertise (T1) & 3 & Less of business friendly policy (S4) \\
\hline 13 & $\begin{array}{l}\text { Lack of practice on reverse logistics } \\
\text { (E3) }\end{array}$ & 4 & Green power shortage $(\mathrm{F} 4)$ \\
\hline 14 & $\begin{array}{l}\text { Lack of environmental requirement } \\
\text { (E2) }\end{array}$ & 5 & Lack of environmental requirement (E2) \\
\hline 15 & $\begin{array}{l}\text { Resistance to change and adopt } \\
\text { innovation (T2) }\end{array}$ & 6 & $\begin{array}{l}\text { Lack of funds for sustainable supply chain } \\
\text { practices (F3) }\end{array}$ \\
\hline 16 & $\begin{array}{l}\text { Lack of funds for sustainable supply } \\
\text { chain practices (F3) }\end{array}$ & 7 & Limited access to market information (KS3) \\
\hline 17 & $\begin{array}{l}\text { Lack demand \& pressure for lower } \\
\text { price (S3) }\end{array}$ & 8 & Capacity constraints (F2) \\
\hline 18 & $\begin{array}{l}\text { Limited access to market information } \\
(\mathrm{KS} 3)\end{array}$ & 9 & Lack of technical expertise (T1 \\
\hline 19 & Green power shortage $(\mathrm{F} 4)$ & 10 & Outdated machineries (T4) \\
\hline 20 & Less of business friendly policy (S4) & 11 & Lack of practice on reverse logistics (E3) \\
\hline
\end{tabular}

Table 10: Weight given to four experts for sensitivity analysis

\begin{tabular}{|c|c|c|c|c|}
\hline & $\begin{array}{c}\text { Expert 1 } \\
\text { (Supply chain } \\
\text { executive) }\end{array}$ & $\begin{array}{c}\text { Expert 2 } \\
\text { (Production } \\
\text { manager) }\end{array}$ & $\begin{array}{c}\text { Expert 3 } \\
\text { (Logistics } \\
\text { executive) }\end{array}$ & $\begin{array}{c}\text { Expert 4 } \\
\text { (Leather } \\
\text { technologist) }\end{array}$ \\
\hline Scenario 1 & 0.4 & 0.2 & 0.2 & 0.2 \\
\hline Scenario 2 & 0.2 & 0.4 & 0.2 & 0.2 \\
\hline Scenario 3 & 0.2 & 0.2 & 0.4 & 0.2 \\
\hline Scenario 4 & 0.2 & 0.2 & 0.2 & 0.4 \\
\hline
\end{tabular}


Table 11: Ranking of cause-effect relationships among common barriers obtained from sensitivity analysis

\begin{tabular}{|c|c|c|c|c|c|c|c|c|}
\hline \multirow{2}{*}{$\begin{array}{c}\text { Rank } \\
\text { order }\end{array}$} & \multicolumn{2}{|c|}{ Scenario 1 } & \multicolumn{2}{c|}{ Scenario 2 } & \multicolumn{2}{c|}{ Scenario 3 } & \multicolumn{2}{c|}{ Scenario 4} \\
\cline { 2 - 9 } & $\begin{array}{c}\text { Barrier } \\
\text { code }\end{array}$ & $r_{i}-c_{j}$ & $\begin{array}{c}\text { Barrier } \\
\text { code }\end{array}$ & $r_{i}-c_{j}$ & $\begin{array}{c}\text { Barrier } \\
\text { code }\end{array}$ & $r_{i}-c_{j}$ & $\begin{array}{c}\text { Barrier } \\
\text { code }\end{array}$ & $r_{i}-c_{j}$ \\
\hline 1 & E4 & 0.888 & E4 & 0.923 & E4 & 0.916 & E4 & 0.879 \\
\hline 2 & KS2 & 0.612 & KS2 & 0.628 & F1 & 0.589 & F1 & 0.582 \\
\hline 3 & F1 & 0.569 & F1 & 0.611 & KS2 & 0.570 & KS2 & 0.582 \\
\hline 4 & E1 & 0.302 & E1 & 0.293 & E1 & 0.329 & E1 & 0.355 \\
\hline 5 & S1 & 0.290 & S2 & 0.276 & S1 & 0.308 & S1 & 0.299 \\
\hline 6 & KS4 & 0.262 & S1 & 0.264 & S2 & 0.275 & KS4 & 0.277 \\
\hline 7 & S2 & 0.258 & KS4 & 0.239 & KS4 & 0.273 & S2 & 0.243 \\
\hline 8 & KS1 & 0.148 & KS1 & 0.132 & KS1 & 0.128 & KS1 & 0.220 \\
\hline 9 & T3 & 0.071 & T3 & 0.055 & T3 & 0.089 & T3 & 0.068 \\
\hline 10 & T2 & -0.077 & T2 & -0.037 & T2 & -0.061 & T2 & -0.079 \\
\hline 11 & S3 & -0.199 & S3 & -0.182 & S4 & -0.206 & S3 & -0.179 \\
\hline 12 & S4 & -0.230 & S4 & -0.230 & S3 & -0.208 & S4 & -0.225 \\
\hline 13 & F4 & -0.264 & F4 & -0.263 & E2 & -0.275 & F3 & -0.266 \\
\hline 14 & E2 & -0.272 & E2 & -0.275 & F4 & -0.276 & F4 & -0.282 \\
\hline 15 & KS3 & -0.276 & KS3 & -0.278 & F3 & -0.302 & E2 & -0.288 \\
\hline 16 & F3 & -0.288 & F3 & -0.304 & KS3 & -0.344 & KS3 & -0.313 \\
\hline 17 & F2 & -0.376 & F2 & -0.374 & F2 & -0.386 & F2 & -0.363 \\
\hline 18 & T1 & -0.435 & T1 & -0.416 & T1 & -0.452 & T1 & -0.435 \\
\hline 19 & T4 & -0.476 & T4 & -0.475 & E3 & -0.477 & T4 & -0.535 \\
\hline 20 & E3 & -0.508 & E3 & -0.589 & T4 & -0.491 & E3 & -0.540 \\
\hline
\end{tabular}




\section{List of Figures}

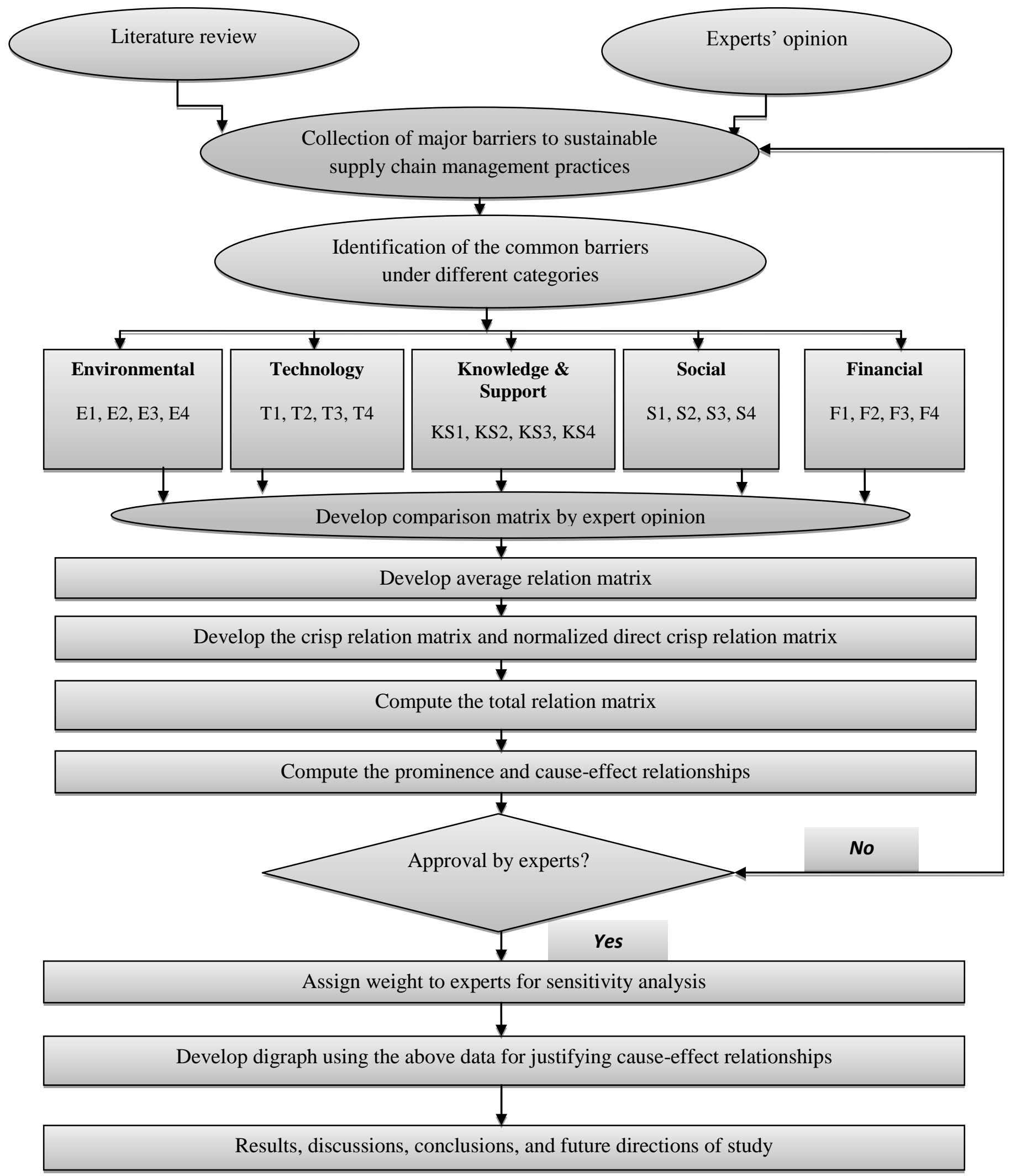

Fig. 1. Conceptual framework for this research 


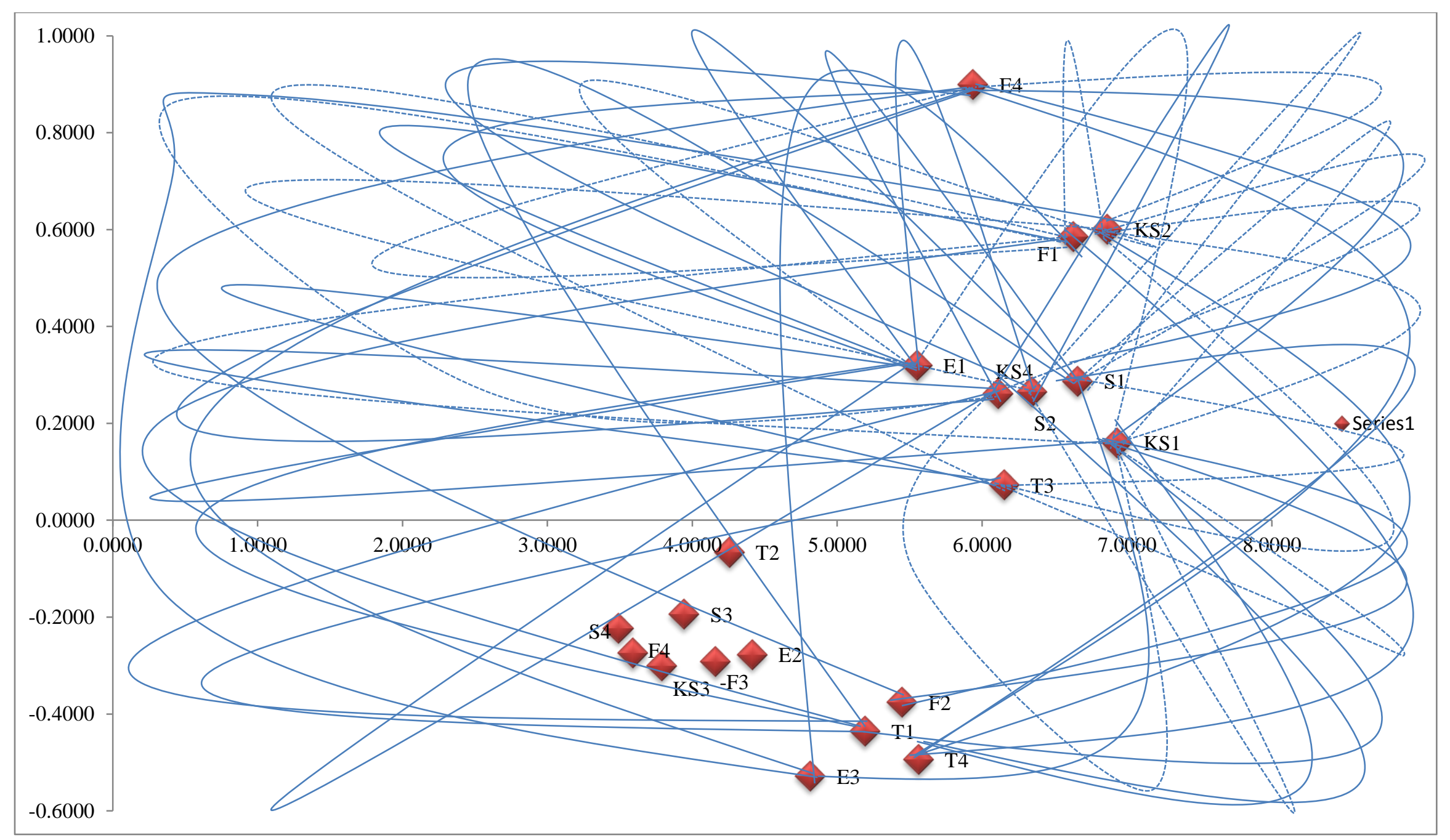

Fig. 2: Digraph showing the causal relationships between the various barriers to implementing SSCM practices 


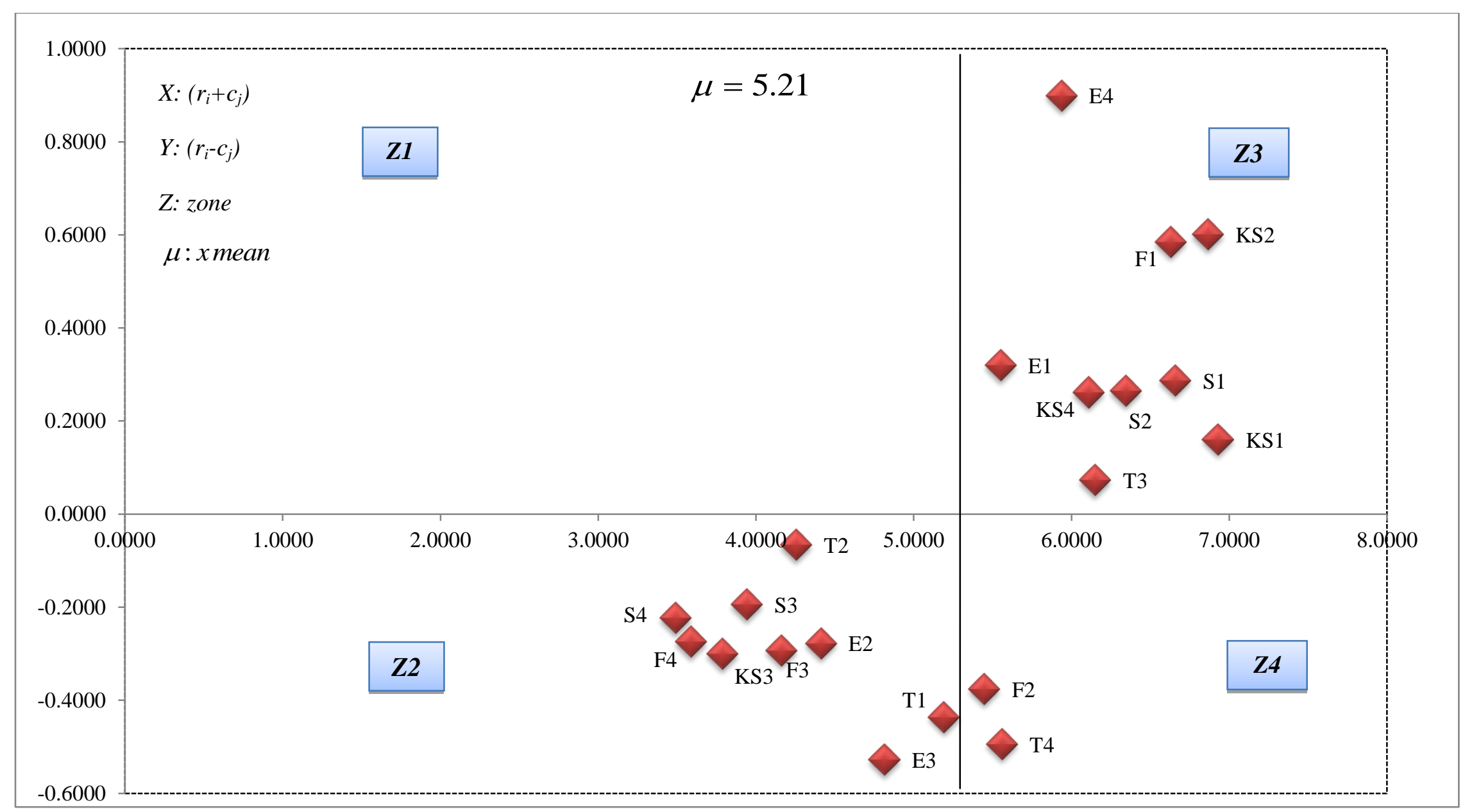

Fig. 3: Barriers of sustainable supply chain management practices represented in zones 


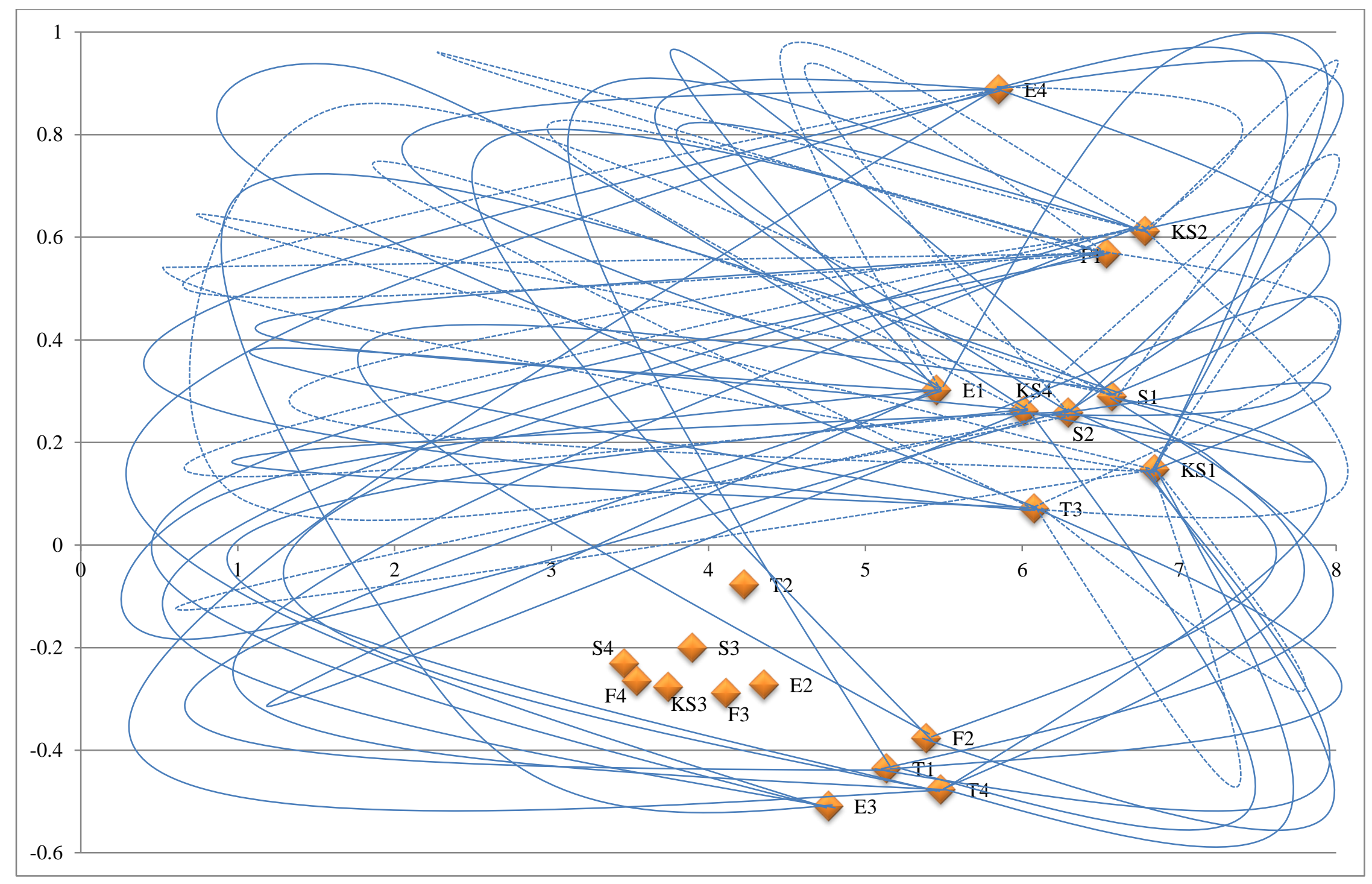

Fig. 4: Digraph obtained during sensitivity analysis showing causal relation among barriers of SSCM practices by giving highest weight to Expert 1 


\section{Annexure 1}

Table A1: Grey relation matrix for barriers of SCCM implementation computed by Expert 1

\begin{tabular}{|c|c|c|c|c|c|c|c|c|c|c|c|c|c|c|c|c|c|c|c|c|}
\hline & E1 & E2 & E3 & E4 & T1 & T2 & T3 & T4 & KS1 & KS2 & KS3 & KS4 & S1 & S2 & S3 & S4 & F1 & F2 & F3 & F4 \\
\hline \multirow[t]{2}{*}{ E1 } & 0 & 0.6 & 0.2 & 0.1 & 0.6 & 0.2 & 0.9 & 0.4 & 0.6 & 0.4 & 0.4 & 0.2 & 0.4 & 0.6 & 0.2 & 0.1 & 0.4 & 0.2 & 0.2 & 0.1 \\
\hline & 0.1 & 0.9 & 0.5 & 0.3 & 0.9 & 0.5 & 1 & 0.7 & 0.9 & 0.7 & 0.7 & 0.5 & 0.7 & 0.9 & 0.5 & 0.3 & 0.7 & 0.5 & 0.5 & 0.3 \\
\hline \multirow[t]{2}{*}{ E2 } & 0.4 & 0 & 0.6 & 0.1 & 0.1 & 0.4 & 0.2 & 0.2 & 0.2 & 0.2 & 0.1 & 0.2 & 0.4 & 0.2 & 0.1 & 0.1 & 0.2 & 0.6 & 0.1 & 0.1 \\
\hline & 0.7 & 0.1 & 0.9 & 0.3 & 0.3 & 0.7 & 0.5 & 0.5 & 0.5 & 0.5 & 0.3 & 0.5 & 0.7 & 0.5 & 0.3 & 0.3 & 0.5 & 0.9 & 0.3 & 0.3 \\
\hline \multirow{2}{*}{$\mathbf{E 3}$} & 0.2 & 0.1 & 0 & 0.2 & 0.2 & 0.6 & 0.4 & 0.6 & 0.4 & 0.4 & 0.2 & 0.2 & 0.2 & 0.2 & 0.1 & 0.1 & 0.2 & 0.6 & 0.1 & 0.1 \\
\hline & 0.5 & 0.3 & 0.1 & 0.5 & 0.5 & 0.9 & 0.7 & 0.9 & 0.7 & 0.7 & 0.5 & 0.5 & 0.5 & 0.5 & 0.3 & 0.3 & 0.5 & 0.9 & 0.3 & 0.3 \\
\hline \multirow[t]{2}{*}{ E4 } & 0.6 & 0.4 & 0.4 & 0 & 0.6 & 0.4 & 0.4 & 0.4 & 0.6 & 0.9 & 0.1 & 0.4 & 0.4 & 0.6 & 0.2 & 0.2 & 0.6 & 0.4 & 0.2 & 0.2 \\
\hline & 0.9 & 0.7 & 0.7 & 0.1 & 0.9 & 0.7 & 0.7 & 0.7 & 0.9 & 1 & 0.3 & 0.7 & 0.7 & 0.9 & 0.5 & 0.5 & 0.9 & 0.7 & 0.5 & 0.5 \\
\hline \multirow[t]{2}{*}{ T1 } & 0.6 & 0.1 & 0.2 & 0.4 & 0 & 0.2 & 0.2 & 0.2 & 0.4 & 0.4 & 0.4 & 0.1 & 0.4 & 0.6 & 0.2 & 0.1 & 0.4 & 0.2 & 0.2 & 0.1 \\
\hline & 0.9 & 0.3 & 0.5 & 0.7 & 0.1 & 0.5 & 0.5 & 0.5 & 0.7 & 0.7 & 0.7 & 0.3 & 0.7 & 0.9 & 0.5 & 0.3 & 0.7 & 0.5 & 0.5 & 0.3 \\
\hline \multirow[t]{2}{*}{ T2 } & 0.2 & 0.1 & 0.6 & 0.2 & 0.2 & 0 & 0.2 & 0.6 & 0.4 & 0.2 & 0.2 & 0.4 & 0.2 & 0.4 & 0.1 & 0.1 & 0.2 & 0.4 & 0.1 & 0.1 \\
\hline & 0.5 & 0.3 & 0.9 & 0.5 & 0.5 & 0.1 & 0.5 & 0.9 & 0.7 & 0.5 & 0.5 & 0.7 & 0.5 & 0.7 & 0.3 & 0.3 & 0.5 & 0.7 & 0.3 & 0.3 \\
\hline \multirow[t]{2}{*}{ T3 } & 0.2 & 0.2 & 0.2 & 0.6 & 0.6 & 0.6 & 0 & 0.2 & 0.6 & 0.4 & 0.4 & 0.4 & 0.4 & 0.4 & 0.2 & 0.1 & 0.6 & 0.4 & 0.6 & 0.2 \\
\hline & 0.5 & 0.5 & 0.5 & 0.9 & 0.9 & 0.9 & 0.1 & 0.5 & 0.9 & 0.7 & 0.7 & 0.7 & 0.7 & 0.7 & 0.5 & 0.3 & 0.9 & 0.7 & 0.9 & 0.5 \\
\hline \multirow[t]{2}{*}{\begin{tabular}{|l|} 
T4 \\
\end{tabular}} & 0.4 & 0.2 & 0.2 & 0.2 & 0.2 & 0.2 & 0.6 & 0 & 0.4 & 0.4 & 0.2 & 0.6 & 0.2 & 0.4 & 0.6 & 0.1 & 0.2 & 0.6 & 0.1 & 0.1 \\
\hline & 0.7 & 0.5 & 0.5 & 0.5 & 0.5 & 0.5 & 0.9 & 0.1 & 0.7 & 0.7 & 0.5 & 0.9 & 0.5 & 0.7 & 0.9 & 0.3 & 0.5 & 0.9 & 0.3 & 0.3 \\
\hline \multirow[t]{2}{*}{ KS1 } & 0.4 & 0.4 & 0.4 & 0.4 & 0.6 & 0.4 & 0.4 & 0.4 & 0 & 0.6 & 0.1 & 0.4 & 0.6 & 0.6 & 0.4 & 0.2 & 0.6 & 0.4 & 0.6 & 0.6 \\
\hline & 0.7 & 0.7 & 0.7 & 0.7 & 0.9 & 0.7 & 0.7 & 0.7 & 0.1 & 0.9 & 0.3 & 0.7 & 0.9 & 0.9 & 0.7 & 0.5 & 0.9 & 0.7 & 0.9 & 0.9 \\
\hline \multirow[t]{2}{*}{ KS2 } & 0.6 & 0.4 & 0.6 & 0.6 & 0.4 & 0.4 & 0.6 & 0.6 & 0.6 & 0 & 0.1 & 0.6 & 0.6 & 0.9 & 0.2 & 0.6 & 0.6 & 0.4 & 0.2 & 0.4 \\
\hline & 0.9 & 0.7 & 0.9 & 0.9 & 0.7 & 0.7 & 0.9 & 0.9 & 0.9 & 0.1 & 0.3 & 0.9 & 0.7 & 1 & 0.5 & 0.9 & 0.9 & 0.7 & 0.5 & 0.7 \\
\hline \multirow[t]{2}{*}{ KS3 } & 0.1 & 0.2 & 0.1 & 0.1 & 0.1 & 0.1 & 0.2 & 0.4 & 0.4 & 0.2 & 0 & 0.2 & 0.2 & 0.4 & 0.1 & 0.4 & 0.2 & 0.1 & 0.6 & 0.2 \\
\hline & 0.3 & 0.5 & 0.3 & 0.3 & 0.3 & 0.3 & 0.5 & 0.7 & 0.7 & 0.5 & 0.1 & 0.5 & 0.5 & 0.7 & 0.3 & 0.7 & 0.5 & 0.3 & 0.9 & 0.5 \\
\hline \multirow{2}{*}{ KS4 } & 0.6 & 0.2 & 0.2 & 0.4 & 0.6 & 0.2 & 0.6 & 0.6 & 0.6 & 0.4 & 0.1 & 0 & 0.4 & 0.6 & 0.6 & 0.1 & 0.6 & 0.2 & 0.2 & 0.1 \\
\hline & 0.9 & 0.5 & 0.5 & 0.7 & 0.9 & 0.5 & 0.9 & 0.9 & 0.9 & 0.7 & 0.3 & 0.1 & 0.7 & 0.9 & 0.9 & 0.3 & 0.9 & 0.5 & 0.5 & 0.3 \\
\hline \multirow[t]{2}{*}{ S1 } & 0.1 & 0.6 & 0.6 & 0.2 & 0.6 & 0.2 & 0.6 & 0.4 & 0.4 & 0.6 & 0.6 & 0.2 & 0 & 0.4 & 0.6 & 0.6 & 0.4 & 0.6 & 0.6 & 0.6 \\
\hline & 0.3 & 0.9 & 0.9 & 0.5 & 0.9 & 0.5 & 0.9 & 0.7 & 0.7 & 0.9 & 0.9 & 0.5 & 0.1 & 0.7 & 0.9 & 0.9 & 0.7 & 0.9 & 0.9 & 0.9 \\
\hline \multirow[t]{2}{*}{ S2 } & 0.4 & 0.4 & 0.4 & 0.4 & 0.4 & 0.2 & 0.6 & 0.4 & 0.9 & 0.6 & 0.2 & 0.4 & 0.6 & 0 & 0.2 & 0.6 & 0.6 & 0.4 & 0.2 & 0.1 \\
\hline & 0.7 & 0.7 & 0.7 & 0.7 & 0.7 & 0.5 & 0.9 & 0.7 & 1 & 0.9 & 0.5 & 0.7 & 0.9 & 0.1 & 0.5 & 0.9 & 0.9 & 0.7 & 0.5 & 0.3 \\
\hline \multirow[t]{2}{*}{ S3 } & 0.1 & 0.2 & 0.1 & 0.2 & 0.2 & 0.1 & 0.2 & 0.1 & 0.2 & 0.4 & 0.2 & 0.6 & 0.2 & 0.1 & 0 & 0.1 & 0.2 & 0.6 & 0.4 & 0.1 \\
\hline & 0.3 & 0.5 & 0.3 & 0.5 & 0.5 & 0.3 & 0.5 & 0.3 & 0.5 & 0.7 & 0.5 & 0.9 & 0.5 & 0.3 & 0.1 & 0.3 & 0.5 & 0.9 & 0.7 & 0.3 \\
\hline \multirow[t]{2}{*}{\begin{tabular}{|l|}
$S 4$ \\
\end{tabular}} & 0.1 & 0.2 & 0.2 & 0.2 & 0.1 & 0.2 & 0.2 & 0.4 & 0.1 & 0.2 & 0.2 & 0.4 & 0.2 & 0.2 & 0.1 & 0 & 0.2 & 0.1 & 0.2 & 0.2 \\
\hline & 0.3 & 0.5 & 0.5 & 0.5 & 0.3 & 0.5 & 0.5 & 0.7 & 0.3 & 0.5 & 0.5 & 0.7 & 0.5 & 0.5 & 0.3 & 0.1 & 0.5 & 0.3 & 0.5 & 0.7 \\
\hline \multirow[t]{2}{*}{ F1 } & 0.6 & 0.4 & 0.4 & 0.6 & 0.6 & 0.4 & 0.6 & 0.4 & 0.9 & 0.6 & 0.2 & 0.4 & 0.6 & 0.2 & 0.2 & 0.1 & 0 & 0.6 & 0.2 & 0.6 \\
\hline & 0.9 & 0.7 & 0.7 & 0.9 & 0.9 & 0.7 & 0.9 & 0.7 & 1 & 0.9 & 0.5 & 0.7 & 0.9 & 0.5 & 0.5 & 0.3 & 0.1 & 0.9 & 0.5 & 0.9 \\
\hline \multirow[t]{2}{*}{ F2 } & 0.2 & 0.4 & 0.6 & 0.4 & 0.2 & 0.2 & 0.2 & 0.6 & 0.4 & 0.4 & 0.2 & 0.1 & 0.6 & 0.4 & 0.2 & 0.2 & 0.4 & 0 & 0.1 & 0.1 \\
\hline & 0.5 & 0.7 & 0.9 & 0.7 & 0.5 & 0.5 & 0.5 & 0.9 & 0.7 & 0.7 & 0.5 & 0.3 & 0.9 & 0.7 & 0.5 & 0.5 & 0.7 & 0.1 & 0.3 & 0.3 \\
\hline F3 & 0.1 & 0.2 & 0.1 & 0.2 & 0.2 & 0.1 & 0.1 & 0.1 & 0.2 & 0.1 & 0.4 & 0.6 & 0.6 & 0.2 & 0.4 & 0.4 & 0.2 & 0.1 & 0 & 0.4 \\
\hline & 0.3 & 0.5 & 0.3 & 0.5 & 0.5 & 0.3 & 0.3 & 0.3 & 0.5 & 0.3 & 0.7 & 0.9 & 0.9 & 0.5 & 0.7 & 0.7 & 0.5 & 0.3 & 0.1 & 0.7 \\
\hline F4 & 0.1 & 0.1 & 0.1 & 0.2 & 0.1 & 0.1 & 0.1 & 0.1 & 0.2 & 0.1 & 0.4 & 0.6 & 0.4 & 0.2 & 0.1 & 0.4 & 0.2 & 0.1 & 0.4 & 0 \\
\hline & 0.3 & 0.3 & 0.3 & 0.5 & 0.3 & 0.3 & 0.3 & 0.3 & 0.5 & 0.3 & 0.7 & 0.9 & 0.7 & 0.5 & 0.3 & 0.7 & 0.5 & 0.3 & 0.7 & 0.1 \\
\hline
\end{tabular}

*E1 indicates the identification code for "Lack of eco-literacy amongst supply chain partner" which is shown in Table 5. Another barrier is also shown in Table

5 by identification code. The level of influence of practices barriers $i$ over $j$ is represented as the grey value $\left[\frac{\otimes y_{i j}}{\overline{\bar{\otimes}} y_{i j}}\right]$. 
Table A2: Crisp relation matrix for barriers to SCCM implementation

\begin{tabular}{|c|c|c|c|c|c|c|c|c|c|c|c|c|c|c|c|c|c|c|c|c|}
\hline & E1 & E2 & E3 & E4 & $\mathrm{T} 1$ & $\mathrm{~T} 2$ & $\mathrm{~T} 3$ & $\mathrm{~T} 4$ & KS1 & $\mathrm{KS} 2$ & $\mathrm{KS} 3$ & KS4 & $\mathrm{S} 1$ & $\mathrm{~S} 2$ & $\mathrm{~S} 3$ & S4 & $\mathrm{F} 1$ & $\mathrm{~F} 2$ & $\mathrm{~F} 3$ & $\mathrm{~F} 4$ \\
\hline E1 & 0 & 0.745 & 0.273 & 0.193 & 0.745 & 0.273 & 0.9 & 0.509 & 0.783 & 0.619 & 0.52 & 0.273 & 0.627 & 0.678 & 0.273 & 0.12 & 0.509 & 0.273 & 0.273 & 0.12 \\
\hline E2 & 0.549 & 0 & 0.782 & 0.129 & 0.129 & 0.549 & 0.293 & 0.301 & 0.293 & 0.295 & 0.173 & 0.301 & 0.549 & 0.295 & 0.129 & 0.129 & 0.301 & 0.782 & 0.129 & 0.129 \\
\hline E3 & 0.273 & 0.12 & 0 & 0.273 & 0.273 & 0.581 & 0.5 & 0.745 & 0.5 & 0.502 & 0.28 & 0.273 & 0.273 & 0.268 & 0.12 & 0.12 & 0.273 & 0.745 & 0.12 & 0.12 \\
\hline E4 & 0.745 & 0.509 & 0.627 & 0 & 0.745 & 0.509 & 0.558 & 0.509 & 0.733 & 0.868 & 0.159 & 0.509 & 0.568 & 0.736 & 0.273 & 0.273 & 0.745 & 0.509 & 0.273 & 0.273 \\
\hline $\mathrm{T} 1$ & 0.745 & 0.12 & 0.273 & 0.509 & 0 & 0.273 & 0.267 & 0.273 & 0.5 & 0.502 & 0.52 & 0.12 & 0.509 & 0.736 & 0.273 & 0.12 & 0.509 & 0.273 & 0.273 & 0.12 \\
\hline $\mathrm{T} 2$ & 0.273 & 0.12 & 0.686 & 0.273 & 0.273 & 0 & 0.267 & 0.745 & 0.5 & 0.268 & 0.28 & 0.509 & 0.273 & 0.502 & 0.12 & 0.12 & 0.273 & 0.509 & 0.12 & 0.12 \\
\hline $\mathrm{T} 3$ & 0.332 & 0.273 & 0.391 & 0.745 & 0.686 & 0.745 & 0 & 0.332 & 0.675 & 0.561 & 0.52 & 0.509 & 0.509 & 0.444 & 0.273 & 0.12 & 0.745 & 0.509 & 0.745 & 0.273 \\
\hline $\mathrm{T} 4$ & 0.509 & 0.273 & 0.273 & 0.273 & 0.273 & 0.273 & 0.733 & 0 & 0.5 & 0.502 & 0.28 & 0.745 & 0.273 & 0.502 & 0.745 & 0.12 & 0.273 & 0.745 & 0.12 & 0.12 \\
\hline KS1 & 0.568 & 0.509 & 0.45 & 0.568 & 0.745 & 0.45 & 0.558 & 0.568 & 0 & 0.736 & 0.159 & 0.568 & 0.745 & 0.678 & 0.509 & 0.273 & 0.745 & 0.509 & 0.745 & 0.745 \\
\hline KS2 & 0.745 & 0.509 & 0.686 & 0.745 & 0.509 & 0.45 & 0.733 & 0.745 & 0.733 & 0 & 0.197 & 0.745 & 0.582 & 0.868 & 0.273 & 0.686 & 0.745 & 0.509 & 0.332 & 0.509 \\
\hline KS3 & 0.12 & 0.273 & 0.12 & 0.12 & 0.12 & 0.12 & 0.267 & 0.509 & 0.442 & 0.268 & 0 & 0.273 & 0.273 & 0.502 & 0.087 & 0.509 & 0.273 & 0.12 & 0.686 & 0.273 \\
\hline KS4 & 0.745 & 0.332 & 0.273 & 0.509 & 0.745 & 0.273 & 0.733 & 0.745 & 0.733 & 0.561 & 0.122 & 0 & 0.509 & 0.736 & 0.745 & 0.155 & 0.745 & 0.273 & 0.273 & 0.155 \\
\hline S1 & 0.193 & 0.745 & 0.745 & 0.273 & 0.745 & 0.273 & 0.733 & 0.509 & 0.675 & 0.678 & 0.64 & 0.273 & 0 & 0.502 & 0.686 & 0.745 & 0.568 & 0.686 & 0.745 & 0.745 \\
\hline $\mathrm{S} 2$ & 0.509 & 0.509 & 0.45 & 0.509 & 0.509 & 0.273 & 0.733 & 0.509 & 0.827 & 0.785 & 0.34 & 0.509 & 0.745 & 0 & 0.273 & 0.627 & 0.745 & 0.509 & 0.273 & 0.155 \\
\hline S3 & 0.12 & 0.273 & 0.155 & 0.273 & 0.273 & 0.12 & 0.267 & 0.155 & 0.267 & 0.502 & 0.28 & 0.745 & 0.273 & 0.119 & 0 & 0.12 & 0.273 & 0.745 & 0.509 & 0.12 \\
\hline S4 & 0.12 & 0.273 & 0.273 & 0.273 & 0.12 & 0.273 & 0.267 & 0.509 & 0.118 & 0.268 & 0.28 & 0.509 & 0.273 & 0.268 & 0.12 & 0 & 0.273 & 0.12 & 0.273 & 0.385 \\
\hline F1 & 0.686 & 0.509 & 0.568 & 0.745 & 0.745 & 0.509 & 0.733 & 0.568 & 0.9 & 0.736 & 0.238 & 0.679 & 0.745 & 0.327 & 0.273 & 0.12 & 0 & 0.745 & 0.273 & 0.745 \\
\hline $\mathrm{F} 2$ & 0.273 & 0.509 & 0.745 & 0.509 & 0.273 & 0.273 & 0.267 & 0.745 & 0.5 & 0.502 & 0.28 & 0.12 & 0.745 & 0.502 & 0.273 & 0.273 & 0.509 & 0 & 0.12 & 0.12 \\
\hline F3 & 0.12 & 0.273 & 0.155 & 0.273 & 0.273 & 0.12 & 0.118 & 0.12 & 0.267 & 0.119 & 0.52 & 0.745 & 0.745 & 0.268 & 0.509 & 0.509 & 0.273 & 0.12 & 0 & 0.509 \\
\hline F4 & 0.12 & 0.12 & 0.12 & 0.273 & 0.12 & 0.12 & 0.118 & 0.12 & 0.267 & 0.119 & 0.52 & 0.745 & 0.509 & 0.268 & 0.12 & 0.509 & 0.273 & 0.12 & 0.509 & 0 \\
\hline
\end{tabular}

Note: Codes are given in Table 5. 
Table A3: Normalized direct crisp relation matrix for barriers to SCCM implementation

\begin{tabular}{|c|c|c|c|c|c|c|c|c|c|c|c|c|c|c|c|c|c|c|c|c|}
\hline & E1 & E2 & $\mathbf{E 3}$ & E4 & T1 & $\mathbf{T} 2$ & T3 & T4 & KS1 & KS2 & KS3 & KS4 & S1 & S2 & S3 & S4 & F1 & F2 & F3 & F4 \\
\hline E1 & 0.000 & 0.066 & 0.024 & 0.017 & 0.066 & 0.024 & 0.080 & 0.045 & 0.069 & 0.055 & 0.046 & 0.024 & 0.055 & 0.060 & 0.024 & 0.011 & 0.045 & 0.024 & 0.024 & 0.011 \\
\hline E2 & 0.049 & 0.000 & 0.069 & 0.011 & 0.011 & 0.049 & 0.026 & 0.027 & 0.026 & 0.026 & 0.015 & 0.027 & 0.049 & 0.026 & 0.011 & 0.011 & 0.027 & 0.069 & 0.011 & 0.011 \\
\hline E3 & 0.024 & 0.011 & 0.000 & 0.024 & 0.024 & 0.051 & 0.044 & 0.066 & 0.044 & 0.044 & 0.025 & 0.024 & 0.024 & 0.024 & 0.011 & 0.011 & 0.024 & 0.066 & 0.011 & 0.011 \\
\hline E4 & 0.066 & 0.045 & 0.055 & 0.000 & 0.066 & 0.045 & 0.049 & 0.045 & 0.065 & 0.077 & 0.014 & 0.045 & 0.050 & 0.065 & 0.024 & 0.024 & 0.066 & 0.045 & 0.024 & 0.024 \\
\hline T1 & 0.066 & 0.011 & 0.024 & 0.045 & 0.000 & 0.024 & 0.024 & 0.024 & 0.044 & 0.044 & 0.046 & 0.011 & 0.045 & 0.065 & 0.024 & 0.011 & 0.045 & 0.024 & 0.024 & 0.011 \\
\hline $\mathbf{T 2}$ & 0.024 & 0.011 & 0.061 & 0.024 & 0.024 & 0.000 & 0.024 & 0.066 & 0.044 & 0.024 & 0.025 & 0.045 & 0.024 & 0.044 & 0.011 & 0.011 & 0.024 & 0.045 & 0.011 & 0.011 \\
\hline T3 & 0.029 & 0.024 & 0.035 & 0.066 & 0.061 & 0.066 & 0.000 & 0.029 & 0.060 & 0.050 & 0.046 & 0.045 & 0.045 & 0.039 & 0.024 & 0.011 & 0.066 & 0.045 & 0.066 & 0.024 \\
\hline T4 & 0.045 & 0.024 & 0.024 & 0.024 & 0.024 & 0.024 & 0.065 & 0.000 & 0.044 & 0.044 & 0.025 & 0.066 & 0.024 & 0.044 & 0.066 & 0.011 & 0.024 & 0.066 & 0.011 & 0.011 \\
\hline KS1 & 0.050 & 0.045 & 0.040 & 0.050 & 0.066 & 0.040 & 0.049 & 0.050 & 0.000 & 0.065 & 0.014 & 0.050 & 0.066 & 0.060 & 0.045 & 0.024 & 0.066 & 0.045 & 0.066 & 0.066 \\
\hline KS2 & 0.066 & 0.045 & 0.061 & 0.066 & 0.045 & 0.040 & 0.065 & 0.066 & 0.065 & 0.000 & 0.017 & 0.066 & 0.051 & 0.077 & 0.024 & 0.061 & 0.066 & 0.045 & 0.029 & 0.045 \\
\hline KS3 & 0.011 & 0.024 & 0.011 & 0.011 & 0.011 & 0.011 & 0.024 & 0.045 & 0.039 & 0.024 & 0.000 & 0.024 & 0.024 & 0.044 & 0.008 & 0.045 & 0.024 & 0.011 & 0.061 & 0.024 \\
\hline KS4 & 0.066 & 0.029 & 0.024 & 0.045 & 0.066 & 0.024 & 0.065 & 0.066 & 0.065 & 0.050 & 0.011 & 0.000 & 0.045 & 0.065 & 0.066 & 0.014 & 0.066 & 0.024 & 0.024 & 0.014 \\
\hline S1 & 0.017 & 0.066 & 0.066 & 0.024 & 0.066 & 0.024 & 0.065 & 0.045 & 0.060 & 0.060 & 0.057 & 0.024 & 0.000 & 0.044 & 0.061 & 0.066 & 0.050 & 0.061 & 0.066 & 0.066 \\
\hline S2 & 0.045 & 0.045 & 0.040 & 0.045 & 0.045 & 0.024 & 0.065 & 0.045 & 0.073 & 0.069 & 0.030 & 0.045 & 0.066 & 0.000 & 0.024 & 0.055 & 0.066 & 0.045 & 0.024 & 0.014 \\
\hline S3 & 0.011 & 0.024 & 0.014 & 0.024 & 0.024 & 0.011 & 0.024 & 0.014 & 0.024 & 0.044 & 0.025 & 0.066 & 0.024 & 0.011 & 0.000 & 0.011 & 0.024 & 0.066 & 0.045 & 0.011 \\
\hline S4 & 0.011 & 0.024 & 0.024 & 0.024 & 0.011 & 0.024 & 0.024 & 0.045 & 0.010 & 0.024 & 0.025 & 0.045 & 0.024 & 0.024 & 0.011 & 0.000 & 0.024 & 0.011 & 0.024 & 0.034 \\
\hline F1 & 0.061 & 0.045 & 0.050 & 0.066 & 0.066 & 0.045 & 0.065 & 0.050 & 0.080 & 0.065 & 0.021 & 0.060 & 0.066 & 0.029 & 0.024 & 0.011 & 0.000 & 0.066 & 0.024 & 0.066 \\
\hline F2 & 0.024 & 0.045 & 0.066 & 0.045 & 0.024 & 0.024 & 0.024 & 0.066 & 0.044 & 0.044 & 0.025 & 0.011 & 0.066 & 0.044 & 0.024 & 0.024 & 0.045 & 0.000 & 0.011 & 0.011 \\
\hline F3 & 0.011 & 0.024 & 0.014 & 0.024 & 0.024 & 0.011 & 0.010 & 0.011 & 0.024 & 0.011 & 0.046 & 0.066 & 0.066 & 0.024 & 0.045 & 0.045 & 0.024 & 0.011 & 0.000 & 0.045 \\
\hline F4 & 0.011 & 0.011 & 0.011 & 0.024 & 0.011 & 0.011 & 0.010 & 0.011 & 0.024 & 0.011 & 0.046 & 0.066 & 0.045 & 0.024 & 0.011 & 0.045 & 0.024 & 0.011 & 0.045 & 0.000 \\
\hline
\end{tabular}

Note: Codes are given in Table 5. 